\title{
An annotated list of parasites (Isopoda, Copepoda, Monogenea, Digenea, Cestoda and Nematoda) collected in groupers (Serranidae, Epinephelinae) in New Caledonia emphasizes parasite biodiversity in coral reef fish
}

\author{
Jean-Lou Justine ${ }^{1,2}$, Ian Beveridge ${ }^{3}$, Geoffrey A. Boxshall ${ }^{4}$, Rod A. Bray ${ }^{4}$, František Moravec ${ }^{5}$, Jean-Paul \\ Trilles $^{6}$ and Ian D. Whittington ${ }^{7}$
}

\author{
${ }^{1}$ UMR 7138 Systématique, Adaptation, Évolution, Muséum National d’Histoire Naturelle, 57, rue Cuvier, 75231 Paris cedex 05, \\ France; \\ ${ }^{2}$ Aquarium des Lagons, BP 8185, 98807 Nouméa, Nouvelle-Calédonie; \\ ${ }^{3}$ Department of Veterinary Science, University of Melbourne, Veterinary Clinical Centre, Werribee 3030, Victoria, Australia; \\ ${ }^{4}$ Department of Zoology, Natural History Museum, Cromwell Road, London SW7 5BD, UK; \\ ${ }^{5}$ Institute of Parasitology, Biology Centre of the Academy of Sciences of the Czech Republic, Branišovská 31, 37005 České \\ Budějovice, Czech Republic; \\ ${ }^{6}$ Équipe Adaptation écophysiologique et Ontogenèse, UMR 5119 (CNRS-UM2-IFREMER), Université Montpellier 2, Place \\ Eugène Bataillon, 34095 Montpellier cedex 05, France; \\ ${ }^{7}$ Monogenean Research Laboratory, The South Australian Museum, Adelaide, \& Marine Parasitology Laboratory, \& Australian \\ Centre for Evolutionary Biology and Biodiversity, The University of Adelaide, North Terrace, Adelaide, South Australia, Australia
}

\begin{abstract}
Over a 7-year period, parasites have been collected from 28 species of groupers (Serranidae, Epinephelinae) in the waters off New Caledonia. Host-parasite and parasite-host lists are provided, with a total of 337 host-parasite combinations, including 146 parasite identifications at the species level. Results are included for isopods (5 species), copepods (19), monogeneans (56), digeneans (28), cestodes (12), and nematodes (12). When results are restricted to those 14 fish species for which more than five specimens were examined and to parasites identified at the species level, 109 host-parasite combinations were recorded, with 63 different species, of which monogeneans account for half (32 species), and an average of 4.5 parasite species per fish species. Digenean records were compared for 16 fish species shared with the study of Cribb et al. (2002); based on a total of 90 parasite records identified at the species level, New Caledonia has 17 new records and only seven species were already known from other locations. We hypothesize that the present results represent only a small part of the actual biodiversity, and we predict a biodiversity of 10 different parasite species and 30 host-parasite combinations per serranid. A comparison with a study on Heron Island (Queensland, Australia) by Lester and Sewell (1989) was attempted: of the four species of fish in common and in a total of 91 host-parasite combinations, only six parasites identified at the species level were shared. This suggests strongly that insufficient sampling impairs proper biogeographical or ecological comparisons. Probably only $3 \%$ of the parasite species of coral reef fish are already known in New Caledonia.
\end{abstract}

Keywords: Isopoda, Copepoda, Monogenea, Digenea, Cestoda, Nematoda, Serranidae, Epinephelinae, parasite biodiversity, coral reef, New Caledonia

Coral reefs are, with tropical rain forests, areas of maximum biodiversity (Reaka-Kudla 1997), and are currently threatened (Roberts et al. 2002, Jones et al. 2004). Biodiversity, here considered as the number of different species in an area, although generally presented to the general public with very visible and iconic examples such as birds and mammals, reveals its real importance when the number of small invertebrates is evaluated. Among these, parasites are often neglected in numerical evaluations of biodiversity (Whittington and Chisholm 2003,
Poulin 2004, Bouchet 2006). With the paradigm that each free-living animal has at least one parasite species, and knowing that many parasite species are strictly specific to their host species, it follows that the number of parasite species is at least equal to the number of non-parasitic animal species, and thus that at least half of biodiversity is represented by parasites (Windsor 1998); parasitology should thus be an integral component of any program for biodiversity assessment (Brooks and Hoberg 2000). 
In this paper, we present results obtained on a single subfamily of coral reef fishes, the groupers (Serranidae, Epinephelinae) in an area centred around Nouméa, New Caledonia, South Pacific. The groupers are fish of considerable economic importance, especially in the Indo-Pacific (Ottolenghi et al. 2004) and diseases, including parasites, may threaten attempts to introduce these species to systems of aquaculture (Bondad-Reantaso et al. 2002).

Results are presented as a host-parasite list (Appendix 1), in which all parasites of a given host species are listed, and as a parasite-host list (Appendix 2), in which all hosts are listed for each parasite species. For possible future verification of the data presented, we give a list of specimens deposited in various international collections with their accession numbers (Appendix 3); we insist on the need for deposition of material for any parasitological study, the utility of which has been demonstrated in many cases (e.g. Hoberg et al. 2009, Justine et al. 2009a).

The current dataset includes 28 species of groupers. It is not easy to express the number of parasite species found because of the many cases of unidentified species: these can represent a single quasi-generalist species or a number of cryptic species. If we minimize the numbers by counting all cases of unidentified species as a single 'species', our results include 134 parasite 'species' (5 Isopoda, 19 Copepoda, 56 Monogenea, 28 Digenea, 12 Cestoda, 12 Nematoda, 1 Acanthocephala and 1 Turbellaria). The number of host-parasite combinations recorded (i.e. a parasite associated with a host) is 337, including 146 in which the parasite was identified at the species level.

We attempted to compare the results obtained here with comparable data sets available in the literature. It appeared that very few such data sets are available. Finally, we used only the general survey on parasites of Heron Island (Lester and Sewell 1989), a small coral cay in the southern Great Barrier Reef off Queensland, Australia $\left(23^{\circ} 26^{\prime} \mathrm{S}, 151^{\circ} 54^{\prime} \mathrm{E}\right)$ at the same latitude and approximately $1,500 \mathrm{~km}$ West of New Caledonia. For brevity, no attempts were made to update this general paper with more recent literature, and no detailed attempt was made to discuss, for each fish or for each parasite, which parasites and which host records have been found elsewhere. This has been done, however, for Epinephelus malabaricus and Ep. cyanopodus (Justine and Sigura 2007, Sigura and Justine 2008).

\section{MATERIALS AND METHODS}

\section{Collection of hosts}

Over a 7-year period (2003-2009), fish were collected, generally by fishing with hook and line, sometimes by spear-fishing, and occasionally from the fish market of Nouméa. All specimens come from within the lagoon, the barrier reef or the outer reef slope in a radius of ca. $30 \mathrm{~km}$ around Nouméa. Live fish were kept in a container with seawater and immediately brought back to the laboratory. All fish were measured, weighed and photographed. A unique number (JNC) was assigned to each fish. The parasitological material was then assigned a corresponding JNC number linked to the respective fish host. Measurements of hosts (fork length, FL, in mm; weight, $\mathrm{W}$, in $\mathrm{g}$ ) were taken for possible future comparison of parasite prevalence and host age in other localities and because the monogenean fauna has been shown to change according to fish size (Hinsinger and Justine 2006a, Sigura and Justine 2008). However, for brevity these data are not given in this paper. Host names have been updated using FishBase (Froese and Pauly 2009).

\section{Collection of parasites}

Basically, we used two methods, targeting two different sets of organs, here designated as the 'gills' and the 'abdominal organs'. The two methods, 'gills' and 'abdominal organs' were sometimes used on the same fish, but often the fish were processed only with one method. There are several reasons for this; often, a given grouper species was examined for gill monogeneans (with other gill parasites collected incidentally) until the monogeneans were collected and described, and the collection of monogeneans was so time-consuming that the detailed study of other organs was not practical; later when the monogeneans were known and described, the same fish species was processed in detail for 'abdominal organs', but the gills were not carefully examined for monogeneans. Also, the examination method was adapted according to the colleagues visiting for collection of their particular group of parasites; in these cases, this group was collected as a priority and other groups were collected only partially, or not at all. In the host-parasite list, we counted separately the total number of fish collected, and the number of fish examined for 'gills' and for the 'abdominal organs'; ideally, the latter two numbers should equal the first, but they rarely do. These numbers are however important in understanding the significance of the results, especially when few parasites were collected from a few fish examined.

For the 'gill method', the gills from both sides were removed one by one by cutting them at their extremities and they were examined immediately in seawater. Parasites were collected under a binocular microscope. Monogeneans were removed alive with fine needles and immediately prepared for slides (Justine 2005a). Copepods and isopods were removed with fine pincers or with the help of a fine needle, and immediately fixed in $70 \%$ ethanol. Live gnathiid isopod larvae were sometimes kept in seawater in an attempt to obtain adults (Smit et al. 2003), but without significant results.

For the 'abdominal organ method', the body cavity was opened and all organs were removed. The liver and gonads were separated. The stomach, caeca and intestine were then opened longitudinally with scissors. For about half of the fish (20032006), the digestive tract was then examined under a binocular microscope and the parasites were removed with fine pincers or a pipette. For the other half, we used the 'gut wash method' (Cribb and Bray 2010) in saline (1/4 seawater, 3/4 tap water); this method proved to be more effective and faster than the direct examination method. The gonads were often, but not always, examined under a binocular microscope and were macerated in a small quantity of saline. Cysts of trypanorhynch cestodes were carefully opened with two fine pincers in saline under a binocular microscope, and the living larvae were immediately flattened between two slides or pipetted in boiling saline, to obtain everted tentacles. Digeneans and cestodes from the intestinal lumen were pipetted alive in near-boiling saline. Copepods and isopods were examined and dissected according to routine meth- 
ods (Boxshall et al. 2008, Trilles and Justine 2010). Permanent slides were made from monogeneans, digeneans and cestodes according to routine methods (Justine 2005a, Bray and Justine 2006a, Beveridge et al. 2007, Kuchta et al. 2009a). Nematodes were fixed alive in near-boiling $4 \%$ formalin, or sometimes in boiling $70 \%$ ethanol or near-boiling saline, and later examined in glycerine; specimens were also prepared for scanning electron microscopy (Moravec and Justine 2005). Tetraphyllidean cestode larvae, which are impossible to identify morphologically, were generally fixed in near-boiling saline and kept in absolute ethanol for possible future molecular analysis.

Several organs were almost never examined. For possible comparison with other geographic localities or similar future studies in the same location, it is important to be explicit in describing the flaws in our sampling methods. Parts of the fish almost never examined include the branchiostegal membranes, the fins and the general surface of the body; this certainly decreased our findings of capsalid monogeneans and philometrid nematodes. The heart and blood system were almost never examined, and thus no aporocotylid digenean was recorded. The kidneys, the liver, the general muscle mass and the bones were not examined. The swim bladder was only occasionally examined. The nasal cavities were not opened. No metacercariae were sought in the muscle mass. Anisakid nematode larvae, which are often numerous on the surface of all internal organs, were only occasionally collected. The eyes and the orbits were examined in certain cases, but certainly not extensively; however, several philometrid nematodes were found in these organs. Only parasitic crustaceans and helminths are recorded here, no attempt was made to seek microscopic protistan or myxozoan parasites. The absence in the present results of several parasitic groups which are usually found in the neglected organs cited above is thus not significant. However, the absence of leeches (Hirudinea) in this study of serranids is significant because these parasites are easily found and were efficiently collected, using the same methods, in other families of fishes. The absence of copepods on the skin is also significant, because such parasites are easily spotted at the time of catch and were collected on fishes of other families.

The number of parasite specimens collected has generally been recorded, but for brevity is not mentioned in this study, which focuses on species-level biodiversity.

\section{Identification of parasites}

The specimens, generally collected by J.-L. Justine and his team of students, and sometimes by visiting colleagues, were forwarded to their respective specialists: I. Beveridge (trypanorhynch cestodes), G.A. Boxshall (copepods), R.A. Bray (digeneans), F. Moravec (nematodes), J.-P. Trilles (isopods), I.D. Whittington (capsalid monogeneans) and J.-L. Justine (other monogeneans). The names of cestode orders follow Khalil et al. (1994), updated by Kuchta et al. (2008) and Healy et al. (2009). Monogenean genera (Haliotrema, etc.) sometimes included in the Dactylogyridae are here considered as members of the Ancyrocephalidae. Many specimens have been deposited in recognized collections (Appendix 3); other specimens under study are still in the collections of the various authors but will be eventually deposited in the collection of the Muséum national d'Histoire naturelle (MNHN) and/or in other recognized, curated collections.

Many specimens were not identified to the species level, even in groups in which this is theoretically possible. Publication of this list could be delayed for several years to await better and more comprehensive accuracy; however, it was considered that enough significant data had already been accumulated to warrant publication. Data presented here were compiled in March 2009; results which were not in press at this date but are now published (Trilles and Justine 2010) have not been included.

\section{Abbreviations}

The following abbreviations are used in Tables and Appendices. For all: Unid: Unidentified family.

Isop: Isopoda; Families: Aegi: Aegiidae; Cora: Corallanidae; Cymo: Cymothoidae; Gnat: Gnathiidae.

Cope: Copepoda; Families: Cali: Caligidae; Diss: Dissonidae; Hats: Hatschekiidae; Lern: Lernanthropidae; Lerp: Lernaeopodidae; Penn: Pennellidae; Siph: Siphonostomidae.

Mono: Monogenea; Families: Ancy: Ancyrocephalidae; Caps: Capsalidae; Dipl: Diplectanidae.

Dige: Digenea; Families: Acan: Acanthostomidae; Apor: Aporocotylidae; Bive: Bivesiculidae; Buce: Bucephalidae; Dero: Derogenidae; Didy: Didymozoidae; Fell: Fellodistomatidae; Gorg: Gorgoderidae; Hemi: Hemiuridae; Hiru: Hirudinellidae; Lepo: Lepocreadiidae; Opec: Opecoelidae.

Cest: unclassified Cestoda.

Tryp: Cestoda Trypanorhyncha; Families: Laci: Lacistorhynchidae; Otob: Otobothriidae; Pseu: Pseudotobothriidae.

Both: Cestoda Bothriocephalidea; Family: Both: Bothriocephalidae.

Tetr: Cestoda Tetraphyllidea (no family identified).

Nema: Nematoda; Families: Anis: Anisakidae; Cama: Camallanidae; Capi: Capillariidae; Cucu: Cucullanidae; Phil: Philometridae.

Acantho: Acanthocephala (no family identified).

Abbreviation in text and Tables: NHR: New host record; NGR: New geographical record. HPC: Host-parasite combination; SLIP: Species-level identified parasite; SLIP-HPC: Species-level identified parasite-host-parasite combination.

Institutions: MNHN, Muséum national d'Histoire Naturelle, Paris, France; BMNH, Natural History Museum, London, United Kingdom; USNPC, United States National Parasite Collection, Beltsville, USA; SAMA AHC, South Australian Museum Adelaide, Australian Helminthological Collection, Adelaide, Australia; HCIP, Helminthological Collection, Institute of Parasitology, Biology Centre, Academy of Sciences of the Czech Republic, České Budějovice, Czech Republic; SLZU, School of Life Sciences, Zhongshan University (Sun Yat-sen University), Guangzhou, China; ZRC, Zoological Collection of the Raffles Museum, Singapore; QM, Queensland Museum, Brisbane, Australia.

\section{RESULTS AND DISCUSSION}

The results are presented as a host-parasite list (Appendix 1), a parasite-host list (Appendix 2) and a list of material deposited (Appendix 3). The number of hostparasite combinations found in each fish species is given in Table 1.

\section{Comments on each group}

In these brief comments, we discuss the new records, and analyse our findings from the perspective of the numerical evaluation of biodiversity. In other words, we try to understand the significance of the number of species found in terms of actual parasite biodiversity. 
Fish. Twenty-eight species of groupers were examined; they represent $68 \%$ of the 41 species known in New Caledonia (Fricke and Kulbicki 2007). However, several species mentioned in the ichthyological literature are rare and will probably escape parasitological investigation. In our study, a few large species were studied only on very small numbers of individuals, such as Ep. coioides (1), Ep. fuscoguttatus (2) and Ep. malabaricus (2); no doubt, better sampling would reveal significant additional numbers of parasite species. The giant species Epinephelus lanceolatus (Bloch, 1790) was not studied. There are 159 species of groupers in the world (Heemstra and Randall 1993 ) so the 28 species investigated represent $18 \%$ of the global fauna.

Isopoda. All three identified adult isopod species found belong to the family Corallanidae, and they were already known from throughout the Indo-West Pacific from a variety of localities (Delaney 1989) and hosts.

Argathona rhinoceros is already known from Tetraodon leopardus, Ep. chlorostigma, Ep. tauvina, Va. louti, Ep. malabaricus, and Pl. leopardus (Delaney 1989), and on Ep. coioides and Ep. fuscoguttatus in Indonesia (W. Thorsten, pers. comm.). It was found again on the gills of Ep. malabaricus and Pl. leopardus in New Caledonia. Ep. coioides and Ep. cyanopodus are new host records. New Caledonia is a new geographical record.

Argathona macronema is already known from Ep. tauvina, Diagramma cinerascens, Pseudolabras sp. [sic], Trachichtodes affinis [sic], Cromileptes altivelis, Lutjanus argentimaculatus, $\mathrm{Pl}$. maculatus, and Pl. leopardus (Delaney 1989), on the eye of a sea turtle in Kenya (Monod 1975) and in an unidentified fish in Indonesia (W. Thorsten, pers. comm.); it is also known from coral reef rock, coral rubble and sand (Delaney 1989). It was found again on the gills of Pl. leopardus in New Caledonia. Pl. laevis is a new host record. New Caledonia is a new geographical record.

Lanocira zeylanica is already known from throughout the Indo-West Pacific, but no hosts have been indicated. The species has been collected from sponges (Monod 1933) and from corals (Monod 1933, Jones 1982). Delaney (1989) wrote "there is only one record (this study) of an unidentified Lanocira species collected as temporary parasite of a fish (Variola louti)". Our finding on the body of $\mathrm{Ce}$. boenak is a new host record, and New Caledonia is a new geographical record.

All larval isopods found belonged to the family Gnathiidae. They were found on 12 of the 28 grouper species examined, but it is likely that all species are hosts for them. These larvae cannot be identified at the species level, and some attempts to obtain the adults from praniza larvae did not succeed. The number of gnathiid species represented in these findings could not be evaluated, but it is likely that more than a single species are involved.
Copepoda. Nineteen 'species' of copepods were recorded from the gills, but this number is reduced by siphonostomatoid and pennellid larvae which were each counted as a single 'species'. Seventeen species of adults were found which belong to the four families Caligidae (5 species), Dissonidae (1 species), Lernanthropidae (1 species) and mainly the Hatschekiidae (10 species). The host-parasite relationships of Dissonus manteri have been discussed (Boxshall et al. 2008).

Numerous specimens of hatschekiids were collected and only two described species could be identified, the other specimens representing eight new species (Fig. 1B$\mathrm{H})$. Hatschekia plectropomi is a distinctive species originally described from $\mathrm{Pl}$. leopardus in Australian waters (Ho and Dojiri 1978). Pl. laevis is a new host record for this parasite. Hatschekia cernae (Fig. 1A) was originally described from Ep. aeneus in the Mediterranean (Goggio 1905), and was subsequently reported from $E p$. fasciatus (as Ep. alexandrinus) and Ep. marginatus (as Ep. gigas) off the West African coast (Nunes-Ruivo 1954, Capart 1959 - as Hatschekia epinepheli). It was first reported from the Pacific from Epinephelus sp. off Okinawa (Shiino 1957). The record from Ep. morrhua is new. There is clearly a radiation of Hatschekia within the groupers, and our evaluation of copepod biodiversity is probably an underestimate of the actual situation. The undescribed Hatschekia species include a generalist species, Hatschekia sp. 1 (Fig. 1B), found on the gills of eight species of hosts, and seven strictly-specific species (Fig. 1C-H) each found only on one host (six cases) or two hosts (one case). It is not unlikely that most species of groupers have their own Hatschekia species, sometimes in addition to the generalist species.

All species of the genus Sagum, with the exception of Sagum texanum and $S$. vespertilio, are specific to serranids of the genus Epinephelus. Sagum epinepheli was originally described from Japanese waters on Ep. akaara (Yamaguti and Yamasu 1960) and subsequently reported from Epinephelus sp. off Kerala, India (Pillai and Sebastian 1967). In our samples it occurred on Pl. leopardus and five species of Epinephelus, all of which are new host records.

Caligus asymmetricus is primarily a parasite of scombrids, and has been reported from more than ten host species taken across the Indo-Pacific (Kabata 1965, Lewis 1967, Cressey and Cressey 1980). It is rarely found on non-scombrid hosts and our report is a new host record.

Lepeophtheirus plectropomi was first discovered on Ep. maculatus in Madagascar (Nunes-Ruivo and Fourmanoir 1956) and was found again in Australia waters on the same fish (Kabata 1966) and on Pl. leopardus and Ep. quoyanus (as Ep. megachir) (Ho and Dojiri 1977). Our records of this parasite from Ep. cyanopodus and Ep. malabaricus are both new. However, we did not find L. plectropomi on Ep. maculatus; instead, this host, together 

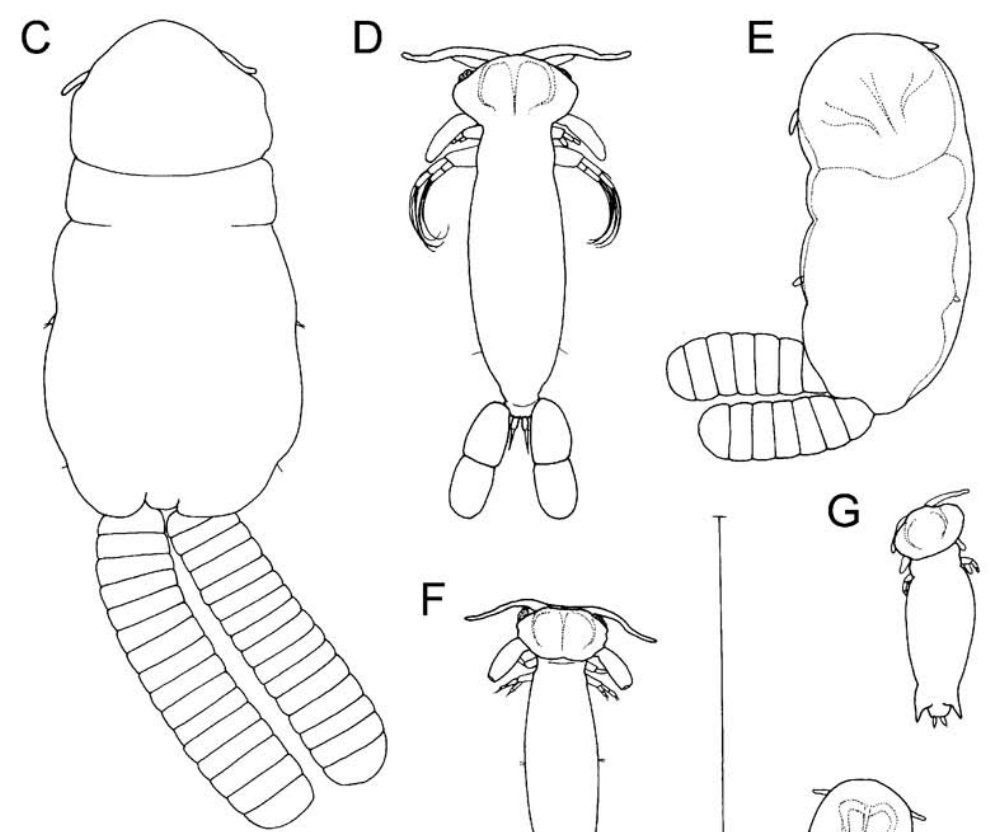

$\mathrm{H}$
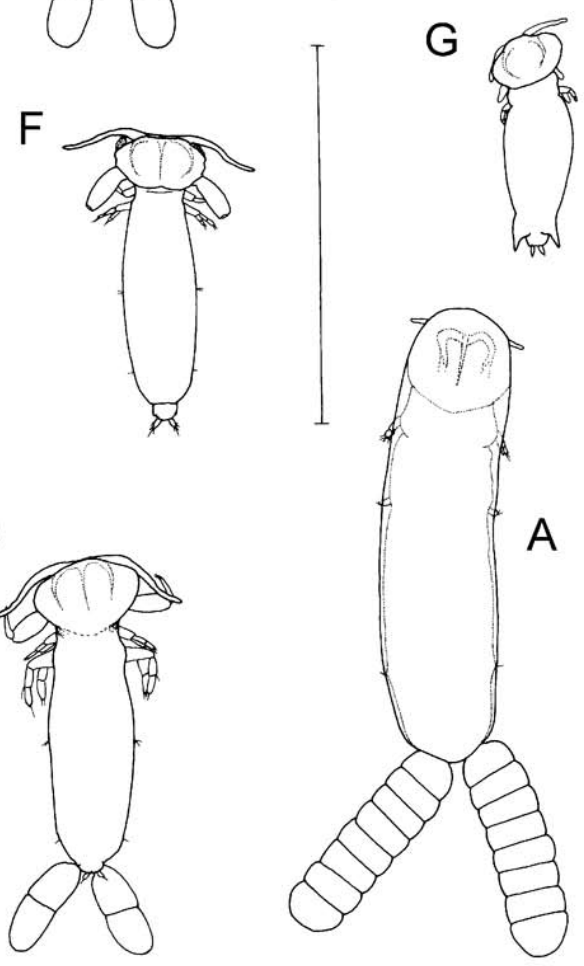

Fig. 1. Species of Hatschekia. A-Hatschekia cernae Goggio, 1905; B - Hatschekia sp. 1 (generalist species); C-Hatschekia sp. 11; D-Hatschekia sp. 5; E-Hatschekia sp. 10; F-Hatschekia sp. 4; G-Hatschekia sp. 8; H - Hatschekia sp. 2. All drawn to same scale. Scale bar $=1.0 \mathrm{~mm}$.

with Ep. coeruleopunctatus, harboured L. epinepheli, first described from Australian waters on Ce. cyanostigma, Ep. cyanopodus (as Ep. hoedti) and Ep. quoyanus (as Ep. gilberti) (Ho and Dojiri 1977).

No copepod was found on the skin of the serranids examined, although these are easily seen and collected on other families of fish.

Monogenea. Fifty-six 'species' of monogeneans were recorded. This number is an underestimate as groups of Haliotrema and Pseudorhabdosynochus were counted each as one 'species' but probably represent about 20 different species. Nevertheless, the monogeneans represent the richest group of parasites found in serranids. Only three families are represented: the Ancyrocephalidae, Capsalidae and Diplectanidae.
The Ancyrocephalidae includes many species reported here as Haliotrema but which might well represent an independent genus, characterised by tubular male copulatory organs. These species have not been studied in detail but it is likely that a significant number of different species is present.

The Capsalidae includes seven 'species' belonging to at least seven genera. Additional work will be needed, both at the morphological and molecular level, to characterize all the species involved (Perkins et al. 2009). It is also important to mention that the biodiversity of capsalids described here is restricted to the species from the gills; species from other sites such as the branchiostegal membranes, fins and skins were generally not collected, and would probably at least double the number of capsalid species found. 
Table 1. Number of host-parasite combinations (HPCs) found in 28 species of serranids in New Caledonia.

\begin{tabular}{|c|c|c|c|c|c|c|c|c|c|c|c|c|c|c|}
\hline \multirow[b]{2}{*}{ Fish species } & \multicolumn{3}{|c|}{ Number of fish examined } & \multicolumn{10}{|c|}{ Host-parasite combinations } & \multirow[t]{2}{*}{$\begin{array}{l}\text { Identifications } \\
\text { at species level }\end{array}$} \\
\hline & $\begin{array}{c}\text { Total } \\
\text { number }\end{array}$ & $\begin{array}{l}\text { For gill } \\
\text { parasites }\end{array}$ & $\begin{array}{l}\text { For abdom- } \\
\text { inal organ } \\
\text { parasites }\end{array}$ & Isop & Cope & Mono & Dige & Both & Tetr & Tryp & Nema & Others & Total & \\
\hline Anyperodon leucogrammicus & 3 & 2 & 1 & 0 & 1 & 2 & 0 & 0 & 0 & 0 & 0 & 0 & 3 & 0 \\
\hline Cephalopholis aurantia $\times$ spiloparaea & 1 & 1 & 1 & 0 & 1 & 0 & 0 & 1 & 0 & 0 & 0 & 0 & 2 & 1 \\
\hline Cephalopholis argus & 5 & 4 & 1 & 1 & 0 & 2 & 1 & 0 & 0 & 0 & 1 & 0 & 5 & 2 \\
\hline Cephalopholis boenak & 59 & 42 & 18 & 2 & 0 & 0 & 1 & 0 & 1 & 2 & 1 & 0 & 7 & 4 \\
\hline Cephalopholis miniata & 3 & 3 & 3 & 0 & 0 & 4 & 2 & 0 & 1 & 2 & 1 & 0 & 10 & 3 \\
\hline Cephalopholis sonnerati & 8 & 7 & 5 & 0 & 1 & 4 & 0 & 0 & 1 & 1 & 1 & 0 & 8 & 3 \\
\hline Cephalopholis spiloparaea & 2 & 1 & 2 & 0 & 1 & 0 & 0 & 0 & 1 & 1 & 0 & 0 & 3 & 0 \\
\hline Cephalopholis urodeta & 38 & 32 & 19 & 1 & 1 & 2 & 4 & 0 & 1 & 2 & 1 & 0 & 12 & 5 \\
\hline Cromileptes altivelis & 4 & 4 & 2 & 0 & 1 & 1 & 0 & 0 & 0 & 0 & 1 & 0 & 3 & 0 \\
\hline Epinephelus areolatus & 14 & 9 & 12 & 1 & 0 & 3 & 3 & 0 & 1 & 0 & 3 & 0 & 11 & 3 \\
\hline Epinephelus chlorostigma & 1 & 1 & 1 & 0 & 2 & 5 & 5 & 0 & 1 & 2 & 1 & 0 & 16 & 5 \\
\hline Epinephelus coeruleopunctatus & 7 & 5 & 5 & 0 & 3 & 4 & 3 & 0 & 0 & 0 & 0 & 0 & 10 & 4 \\
\hline Epinephelus coioides & 1 & 1 & 1 & 1 & 0 & 6 & 0 & 0 & 0 & 2 & 2 & 0 & 11 & 4 \\
\hline Epinephelus cyanopodus & 25 & 21 & 14 & 2 & 7 & 9 & 7 & 0 & 1 & 2 & 3 & 0 & 31 & 20 \\
\hline Epinephelus fasciatus & 92 & 45 & 61 & 0 & 2 & 3 & 9 & 0 & 1 & 2 & 3 & 1 & 21 & 10 \\
\hline Epinephelus fuscoguttatus & 2 & 2 & 1 & 1 & 3 & 3 & 0 & 0 & 0 & 0 & 1 & 0 & 8 & 0 \\
\hline Epinephelus howlandi & 24 & 23 & 3 & 1 & 0 & 2 & 0 & 0 & 0 & 1 & 1 & 0 & 5 & 3 \\
\hline Epinephelus maculatus & 62 & 38 & 38 & 1 & 5 & 13 & 12 & 1 & 1 & 1 & 2 & 0 & 36 & 19 \\
\hline Epinephelus malabaricus & 2 & 2 & 2 & 1 & 3 & 11 & 2 & 0 & 0 & 2 & 1 & 0 & 20 & 12 \\
\hline Epinephelus merra & 64 & 58 & 18 & 0 & 4 & 3 & 2 & 0 & 0 & 0 & 0 & 0 & 9 & 4 \\
\hline Epinephelus morrhua & 5 & 5 & 4 & 1 & 3 & 3 & 4 & 0 & 1 & 1 & 1 & 1 & 15 & 5 \\
\hline Epinephelus polyphekadion & 8 & 6 & 3 & 1 & 1 & 4 & 2 & 1 & 0 & 1 & 0 & 0 & 10 & 1 \\
\hline Epinephelus retouti & 2 & 1 & 2 & 0 & 0 & 1 & 3 & 0 & 0 & 1 & 2 & 0 & 7 & 2 \\
\hline Epinephelus rivulatus & 14 & 14 & 8 & 1 & 1 & 3 & 2 & 0 & 1 & 2 & 1 & 0 & 11 & 5 \\
\hline Plectropomus laevis & 14 & 14 & 6 & 1 & 3 & 2 & 3 & 1 & 0 & 3 & 2 & 0 & 15 & 8 \\
\hline Plectropomus leopardus & 42 & 21 & 24 & 2 & 5 & 4 & 4 & 0 & 1 & 3 & 1 & 0 & 20 & 12 \\
\hline Variola albimarginata & 4 & 4 & 2 & 1 & 2 & 1 & 1 & 0 & 0 & 0 & 3 & 0 & 8 & 2 \\
\hline Variola louti & 34 & 28 & 18 & 1 & 3 & 2 & 6 & 0 & 0 & 4 & 4 & 0 & 20 & 9 \\
\hline Total & 540 & 394 & 275 & 20 & 53 & 97 & 76 & 4 & 13 & 35 & 37 & 2 & 337 & 146 \\
\hline
\end{tabular}

The Diplectanidae represents the major monogenean family in the serranids, with four genera, Pseudorhabdosynochus (33 identified species), Diplectanum (4 identified species), Laticola (2 species) and Echinoplectanum (5 species). Species from groupers included in Diplectanum have been only provisionally attributed to the genus and probably deserve their own genus (Justine 2007b,c, 2008a, Justine and Sigura 2007). Species of Echinoplectanum are found only in the coralgroupers (Plectropomus spp.) and never in the other groupers (Justine and Euzet 2006). Although the genus Pseudorhabdosynochus is the most species-rich of the diplectanids (Justine 2007b), our results underestimate diplectanid biodiversity because at least a dozen undescribed Pseudorhabdosynochus species were found (Appendices 1,2). We found that some groupers have an outstanding monogenean biodiversity, with six to eight species of Pseudorhabdosynochus found in Ep. cyanopodus, Ep. malabaricus, and Ep. maculatus (Appendix 1). In total, 42 diplectanids were identified from the fish sampled in New Caledonia (Appendix 2); however, when all of the undescribed Pseudorhabdosynochus found here have been described, we believe that there will probably be 60 species known from the groupers off New Caledonia.
No Lamellodiscus spp. were found in the serranids examined; this suggests that records of members of this diplectanid genus in groupers are probably accidental (Justine 2009, Justine and Briand 2010). All fish examined here were taken from the wild and were not kept in tanks with other fish, a possible cause of accidental monogenean contamination (Justine 2009).

A significant absence in serranids was the polyopisthocotylean monogeneans, specimens of which were not found in our study.

Digenea. Twenty-eight 'species' of digeneans were recorded, but this number is greatly reduced by juvenile and adult didymozoids being counted as a single 'species'.

In contrast to all other digeneans cited in this study, which inhabit the lumen of the digestive system, the didymozoids are adults in closed cysts and have 'larvae' (or rather 'juveniles') which are found in the lumen of the digestive tract and occasionally on the gills. Adult didymozoids probably show a certain degree of host specificity, but all species recorded here in serranids have tangled filiform bodies which are extremely time-consuming to prepare for slides; it is likely that several species are present, but specimens have not been thoroughly examined to as- 
certain this. Juvenile didymozoids are found in almost all families of fish and no attempt was made to separate the forms (Pozdnyakov and Gibson 2008) according to their morphology; it is likely that these juvenile didymozoids represent considerable biodiversity, but this is probably not specific to the serranids. Unidentified adult didymozoids, generally filiform species in cysts, were found in seven fish species. Juvenile didymozoids, generally free in the intestinal lumen or on gills, were found in six species; it is likely that these juveniles are in fact actually present in all serranid species, as they are in most other fish as well (unpublished observations).

In addition to the didymozoids, the families represented include three species-rich families, the Bucephalidae, Hemiuridae and Opecoelidae. The Bucephalidae has six 'species', including Prosorhynchus longisaccatus in three hosts; unidentified Prosorhynchus species might represent additional biodiversity, since species in this genus show some degree of host specificity. Six 'species' of Hemiuridae were found. These include a series of unidentified Lecithochirium forms from six hosts. The Opecoelidae includes seven 'species', including Cainocreadium epinepheli, apparently a generalist digenean species, found in eight hosts species, and Allopodocotyle epinepheli and Helicometra epinepheli found respectively in three and two host species. Families represented by few species include the Acanthocolpidae, with the single species Stephanostomum japonocasum found in seven host species; the Bivesiculidae, with two 'species', Bivesicula claviformis in Ce. boenak and an unidentified Bivesicula species in three other fish species. The Derogenidae, Fellodistomatidae, Gorgoderidae and Lepocreadiidae, were each represented by a single species.

Further comment on the identity of the opecoelid species Helicometra epinepheli is desirable. Durio and Manter (1968b) in recording a Helicometra species from Epinephelus sp. off New Caledonia could see no reason for separating $H$. epinepheli from the apparently widespread species H. fasciata. Sekerak and Arai (1974) in their review of the genus concurred, but considered $H$. pulchella the valid name, with both $H$. fasciata and $H$. epinepheli amongst a long list of synonyms (Sekerak and Arai 1974). However, enzyme electrophoretic studies in the Mediterranean indicated (Reversat et al. 1989, 1991, Reversat and Silan 1993) that morphologically indistinguishable Helicometra forms constituted a complex of three species. In view of this we consider it best to use the name $H$. epinepheli for the species from serranids believing that it is unlikely that they are conspecific with the forms from sparids, gobiids and anguillids in the Mediterranean Sea and Atlantic Ocean.

The digeneans allow further comparison because an extensive bibliographical study of the digeneans of groupers has been published (Cribb et al. 2002). The 10 digenean families found here represent more than half of the 17 families recorded in groupers. The 16 genera recorded here represent one third of the 50 genera recorded for all digeneans of groupers of the Indo-West Pacific. Most of 'missing' families have only a small number of genera and species recorded.

Table 2 summarises a comparison between our results and the general work of Cribb et al. (2002). Sixteen of the serranid species listed in Cribb et al. (2002) were also investigated in the present study. In the 16 fish species in common, Cribb et al. (2002) listed 73 digenean species and we found 24 species. The total number of species reported by Cribb et al. (2002) and in this study is 90 , not 97 $(73+24)$ because of the species in common. The striking result is that, of the 24 digenean species found in New Caledonia, 17 are new records and 7 have already been found in the same fish species.

Table 2. Comparison of digeneans recorded in groupers of the Indo-Pacific (Cribb et al. 2002) and present results. Fish which were not listed in Cribb et al. (2002) are not listed here (i.e. many new records are not indicated).

\begin{tabular}{lrcccc}
\hline Fish species & $\begin{array}{c}\text { Number } \\
\text { of species } \\
\text { in Cribb } \\
\text { et al. }\end{array}$ & $\begin{array}{c}\text { Number } \\
\text { of species } \\
\text { in NC } \\
\text { (Present } \\
\text { paper) }\end{array}$ & $\begin{array}{c}\text { Total } \\
\text { number } \\
\text { of spe- } \\
\text { cies }\end{array}$ & $\begin{array}{c}\text { Species } \\
\text { found in } \\
\text { NC and } \\
\text { already } \\
\text { recorded }\end{array}$ \\
$\begin{array}{l}\text { Cephalopholis boenak } \\
\text { in NC }\end{array}$ \\
Cephalopholis miniata & 2 & 1 & 3 & 0 & 1 \\
Cephalopholis sonnerati & 4 & 1 & 5 & 0 & 1 \\
Cephalopholis urodeta & 4 & 0 & 4 & 0 & 0 \\
Cromileptes altivelis & 0 & 2 & 2 & 0 & 2 \\
Epinephelus areolatus & 1 & 0 & 1 & 0 & 0 \\
Epinephelus chlorostigma & 4 & 2 & 9 & 0 & 2 \\
Epinephelus cyanopodus & 6 & 4 & 10 & 0 & 4 \\
Epinephelus fasciatus & 13 & 4 & 14 & 3 & 1 \\
Epinephelus fuscoguttatus & 1 & 0 & 1 & 0 & 0 \\
Epinephelus malabaricus & 4 & 1 & 5 & 0 & 1 \\
Epinephelus merra & 11 & 2 & 12 & 1 & 1 \\
Epinephelus polyphekadion & 2 & 0 & 2 & 0 & 0 \\
Plectropomus leopardus & 7 & 1 & 7 & 1 & 0 \\
Variola albimarginata & 1 & 1 & 2 & 0 & 1 \\
Variola louti & 6 & 4 & 8 & 2 & 2 \\
\hline Total & 73 & 24 & 90 & 7 & 17 \\
\hline & & & & & 1 \\
\hline
\end{tabular}

Table 3 lists all new records and species which have already been found in the same fish species at other locations. Most species here are common species, such as Cainocreadium epinepheli, which have been recorded in many hosts. This suggests that the high number of new records in the present study is simply a consequence of better sampling, but sample sizes cannot be compared because no such information is available in the study by Cribb et al. (2002) which is based on a compilation of the literature. These major differences obtained for common species probably preclude any serious biogeographical conclusions on other digenean species and about the New Caledonian fauna of grouper digeneans. 
Table 3. Digeneans in serranids: comparisons between the list of records (Cribb et al. 2002) and our records in New Caledonia, including new records and species already recorded.

\begin{tabular}{lll}
\hline Fish species & NC as new record & Found in NC, already recorded \\
\hline $\begin{array}{l}\text { Cephalopholis boenak } \\
\text { Cephalopholis miniata }\end{array}$ & Bive: Bivesicula claviformis & \\
Opephalopholis urodeta Cainocreadium epinepheli & Acan: Stephanostomum japonocasum & \\
& Opec: Cainocreadium epinepheli & \\
Epinephelus areolatus & Acan: Stephanostomum japonocasum & \\
& Buce: Prosorhynchus longisaccatus & \\
Epinephelus chlorostigma & Acan: Stephanostomum japonocasum & \\
Epinephelus cyanopodus & Buce: Prosorhynchus longisaccatus & \\
& Hemi: Erilepturus hamati \\
& Opec: Allopodocotyle epinepheli & \\
Epinephelus fasciatus & Opec: Cainocreadium epinepheli & \\
& Opec: Cainocreadium epinepheli & Lepo: Lepidapedoides angustus \\
Epinephelus malabaricus & Buce: Prosorhynchus maternus & Opec: Allopodocotyle epinepheli \\
Epinephelus merra & Opec: Allopodocotyle epinepheli & Opec: Helicometra epinepheli \\
Plectropomus leopardus & & Opec: Pacificreadium serrani \\
Variola albimarginata & Buce: Prosorhynchus serrani & \\
Variola louti & Acan: Stephanostomum japonocasum & Buce: Prosorhynchus serrani \\
& Opec: Cainocreadium epinepheli & Opec: Pacificreadium serrani \\
\hline
\end{tabular}

Cestoda Bothriocephalidea. A single case of an adult bothriocephalid was found in the 275 specimens of serranids examined for 'abdominal organs'. This extremely low percentage is certainly significant; adult bothriocephalids are found in only a few other families (Kuchta et al. 2009b). This single case in serranids was found in a fish which had the rare characteristics of being a hybrid of Ce. aurantia $\times C e$. spiloparaea (Randall and Justine 2008) and being a deep-sea fish of the outer slope of the reef. It is not known if one of these factors is significant in this discovery.

A few larval bothriocephalideans were found in the flesh or digestive tract and were impossible to identify to species.

Cestoda Tetraphyllidea. Larval tetraphyllideans were found in the digestive lumen of 13 of the species studied. Because these specimens are very small and easy to overlook, especially with the 'direct examination' method, we consider it is probable that all serranids harbour tetraphyllidean larvae; this is also the case for most carnivorous fishes of other teleost families (unpublished observations).

Tetraphyllideans are parasites of elasmobranchs as adults and their life cycle involves a crustacean and one or several successive teleost intermediate hosts (Euzet 1994). Adult tetraphyllideans have been found in most sharks and rays examined in New Caledonia (Euzet and Justine, unpublished).

Tetraphyllidean larvae are sometimes very small and were probably overlooked; it might be that some species of Lecanicephalidea or Rhinebothriidea are included within these collections.

The degree of biodiversity represented by these tetraphyllideans larvae is not known, but 31 morphotypes were found in labrids of the Great Barrier Reef (Chambers et al. 2000, Muñoz et al. 2007); there is no reason why our samples should not exhibit at least as much diversity.

Cestoda Trypanorhyncha. Eight 'species' of larval trypanorhynchs, including five identified to the species level, have been found; they belong to three families, namely Lacistorhynchidae, Pseudotobothriidae and Otobothriidae. The trypanorhynch larvae found have already been recorded from a number of teleosts hosts (Palm 2004). The detailed lists in Palm (2004) allowed the identification of new host records and new geographical records. All species were found in cysts located in various sites around the body cavity.

Pseudogilquinia pillersi was found in four host species. Three hosts have already been recorded (Beveridge et al. 2007); Pl. leopardus is a new host record. This species is known from Sri Lanka, Australia and New Caledonia.

Pseudolacistorhynchus heroniensis was found in seven host species. Ep. cyanopodus has already been recorded (Sigura and Justine 2008); Ce. boenak, Ep. chlorostigma, Ep. fasciatus, Ep. howlandi, Ep. polyphekadion and Ep. rivulatus are new host records. This species is known only from the east coast of Australia and New Caledonia.

Callitetrarhynchus gracilis was found in four host species, Ce. boenak, Ep. chlorostigma, Ep. rivulatus and Va. louti, which are all new host records. New Caledonia is a new geographical record for this cosmopolitan species.

Floriceps minacanthus was found in six host species. Ep. cyanopodus has already been recorded (Sigura and Justine 2008); Pl. leopardus has been recorded from Heron Island, Australia (Palm 2004) and Va. louti from Egypt, Red Sea (Abdou and Palm 2008) and various locations in the Pacific (Eniwetok, Kiribati) (Palm 2004); New Caledonia is a new geographical record for this species. $C e$. miniata, Ce. urodeta, and $\mathrm{Pl}$. laevis are new host records. 
Pseudotobothrium dipsacum was found in 10 host species. Ce. sonnerati, Ep. malabaricus and Va. louti have already been recorded from Zanzibar, East Africa (Beveridge et al. 2000) and Ep. coioides and Pl. leopardus have already been recorded on Heron Island, Queensland, Australia (Beveridge et al. 2000); New Caledonia is a new geographical record for all these species. Ce. miniata, Ce. urodeta, Ep. fasciatus, Ep. retouti and Pl. laevis are new host records.

Trypanorhynchs are parasite of elasmobranchs as adults, and their life cycle involves a crustacean and one or several successive teleost intermediate hosts (Campbell and Beveridge 1994, Palm 2004). Pseudogilquinia pillersi is apparently restricted to large predatory serranids, suggesting that a smaller fish is involved as the previous host in the life cycle (Beveridge et al. 2007). For the four other species (Pseudolacistorhynchus heroniensis, C. gracilis, F. minacanthus and Pseudotobothrium dipsacum), a main characteristic of the larvae is their absence of host specificity; it is likely that an exhaustive search would find that all serranid species harbour all of these four trypanorhynch species. These four species have also been found in New Caledonia in many carnivorous fishes other than serranids, including lutjanids and lethrinids (Beveridge and Justine, unpublished).

Hosts of adults of $C$. gracilis and F. minacanthus are sharks, including carcharhinids (Carcharhinus spp.) which are abundant in New Caledonian waters. Adult C. gracilis and F. minacanthus have also been collected in the hemigaleid Triaenodon obesus (Rüppell) in New Caledonia (Beveridge and Justine, unpublished). The adult of Pseudolacistorhynchus heroniensis has been found (Beveridge and Justine 2007) in the leopard shark, Stegostoma fasciatum (Hermann), while the host of the adults of Pseudotobothrium dipsacum remains unknown.

Nematoda. Nematodes recorded belong to five families, the Anisakidae, Camallanidae, Capillariidae, Cucullanidae and Philometridae.

The Anisakidae is represented by larvae only, generally encapsulated on the surface of organs or free in the lumen of the digestive tract. Generally, no effort has been made to identify these larvae at the generic level, but some of them were found to belong to the genera Anisakis, Hysterothylacium and Terranova. Specific identification of such larvae on the basis of morphological characters is impossible. These anisakid larvae are found in almost all teleosts and show very little specificity at this stage (Williams and Jones 1994). Fishes harbouring these larvae serve only as paratenic hosts, being apparently, however, the main source of infection for the definitive hosts, mainly piscivorous elasmobranchs, teleosts, marine reptiles and marine mammals (Anderson 2000, Moravec 1994, Williams and Jones 1994).

The Camallanidae includes Procamallanus variolae, found in two host species. Specimens of Capillariidae have been found only in coralgroupers, Plectropomus spp., and have not yet been identified at the species level. Cucullanidae species have been found in the two species of Variola only and have not yet been described.

The Philometridae found here includes three species, which exhibit two distinct specificity strategies. Philometrids from the eye and orbit of five hosts all correspond to the apparently non-specific single species Philometra ocularis, but philometrids from the gonads show a higher degree of host specificity (Moravec and Justine 2008). Until recently, gonad-infecting philometrids from many species of marine teleosts, including some groupers, were reported from various geographical regions as Philometra lateolabracis, a species inadequately described from Japan, with unknown males (Moravec 2006). The recent discovery of the male of $P$. lateolabracis from the type host and type locality (Quiazon et al. 2008a) has made it possible to distinguish this species from other related congeners on the basis of male morphology and thus contributed greatly to the taxonomy of the important gonad-infecting philometrids in general (e.g. Moravec and Justine 2008, 2009, Quizon et al. 2008a,b). Since little or no attention has so far been paid to the examination of the body skin, mouth cavity and fins of New Caledonian serranids, it can be expected that additional representatives of Philometridae will be found in these hosts. Philometrids (species of Philometra, Philometroides and Spirophilometra) utilising these locations within the host are known from serranid fishes in other geographical regions (Moravec 2006; unpublished).

Turbellaria. A single case of a parasitic turbellarian has been found on the gills of Ep. fasciatus. These parasitic forms are very difficult to study because they are fragile and have no sclerotised parts. Similar forms in an acanthurid (Justine et al. 2009b) were referred to Piscinquilinus (Genostomatidae) but the species from the serranids has not been studied in sections and it is not possible to refer it to this genus or to Paravortex (Dalyelliidae). These turbellarian parasites are extremely rare and have been found in only $0.3 \%$ of the fish of various families examined in New Caledonia (Justine et al. 2009b).

Acanthocephala. A single specimen has been found in the deep-sea grouper Ep. morrhua.

\section{A numerical evaluation of parasite biodiversity in serranids}

Table 1 was built by counting each parasitological finding (i.e. each line in Appendix 1) as a host-parasite combination (HPC). Table 1 details the number of HPCs found in each fish species, and indicates how many fish specimens have been examined.

The number of HPCs is different from the actual number of parasite species, for two reasons (a) a parasite species present in several hosts is counted as several 
HPCs; and (b) HPCs in Table 1 enumerate findings which widely range in systematic precision. HPCs may designate:

- species-level identified parasites (SLIPs);

- parasite species identified at the generic level only, but which probably represent only a single species (examples: several digeneans);

- parasite species identified at the generic level only, but for which we already know that they represent a number of different species (example: the monogeneans Pseudorhabdosynochus spp.); these probably represent a total of about 30 species;

- parasite species identified at the family or upper level, for which we know that abundant biodiversity is hidden within this HPC. This includes unidentifiable larvae such as gnathiid isopods, anisakid nematodes, didymozoid digeneans and tetraphyllidean metacestodes. These probably represent about 50 species.

The 337 HPCs shown in Table 1 represent a ratio of about 12 HPCs per fish species. It is likely that better parasite species identification would probably boost the total to over 400 HPCs for the 28 fish species in Table 1, with a ratio of about 14 HPCs per fish species.

Precise comparisons of parasite faunas could only be achieved based on counts of species-level identified parasites (SLIPs) and our sampling (Table 1) was sometimes limited to a small number of fish. Table 4 includes only those fish species for which at least five specimens were studied for both the gills and the abdominal organs and for which SLIPs are available. Accumulation curves (Cribb 1998) show that about half of the digenean diversity found in a sample of 30 fish is found with a sample of five (see also Dove and Cribb 2006). We do not know if these accumulation curves are valid for other groups. Monogeneans generally have species with high prevalence, with the consequence that smaller samples are needed to detect a significant proportion of diversity than for digeneans; on the other hand, sampling has often demonstrated the presence of very rare monogenean species, found only in a few specimens compared to thousands of specimens of the abundant species (Hinsinger and Justine 2006a, Sigura and Justine 2008, Justine and Euzet 2006, Poulin and Justine 2008).

Table 4 shows a total of 109 species-level identified parasite-host-parasite combinations (SLIP-HPCs) for 14 fish species (ca. 7.8 per fish). As with Table 1, the total number of SLIP-HPCs is different from the actual number of different parasite species because certain parasites are found in several fish species. The number of different parasite species was 63 (4.5 per fish).

The ratio of the number of SLIP-HPCs to the number of different parasite species is also shown in Table 4: it differs drastically among parasite groups. Trypanorhynch larvae, with 21 combinations and only five species (4.2 combinations, i.e. as many hosts per species) exemplify a group composed of species with low host specifi-
Table 4. Number of species-level identified parasites (SLIPs) found in those 14 serranid species for which at least 5 specimens were studied for both gills and abdominal organs in New Caledonia.

\begin{tabular}{|c|c|c|c|c|c|c|c|}
\hline Fish & Isop & Cope & Mono & Dige & Tryp & Nema & Total \\
\hline Cephalopholis boenak & 1 & 0 & 0 & 1 & 2 & 0 & 4 \\
\hline Cephalopholis sonnerati & 0 & 0 & 2 & 0 & 1 & 0 & 3 \\
\hline Cephalopholis urodeta & 0 & 0 & 1 & 2 & 2 & 0 & 5 \\
\hline Epinephelus areolatus & 0 & 0 & 0 & 2 & 0 & 1 & 3 \\
\hline $\begin{array}{l}\text { Epinephelus coeruleo- } \\
\text { punctatus }\end{array}$ & 0 & 2 & 1 & 1 & 0 & 0 & 4 \\
\hline Epinephelus cyanopodus & 1 & 4 & 7 & 4 & 2 & 2 & 20 \\
\hline Epinephelus fasciatus & 0 & 0 & 2 & 4 & 2 & 2 & 10 \\
\hline Epinephelus howlandi & 0 & 0 & 2 & 0 & 1 & 0 & 3 \\
\hline Epinephelus maculatus & 0 & 2 & 10 & 7 & 0 & 0 & 19 \\
\hline Epinephelus merra & 0 & 1 & 1 & 2 & 0 & 0 & 4 \\
\hline Epinephelus rivulatus & 0 & 0 & 2 & 0 & 2 & 1 & 5 \\
\hline Plectropomus laevis & 1 & 2 & 2 & 0 & 3 & 0 & 8 \\
\hline Plectropomus leopardus & 2 & 3 & 3 & 1 & 3 & 0 & 12 \\
\hline Variola louti & 0 & 0 & 1 & 4 & 3 & 1 & 9 \\
\hline Number of SLIP-HPCs & 5 & 14 & 34 & 28 & 21 & 7 & 109 \\
\hline $\begin{array}{l}\text { Number of different } \\
\text { parasite species }\end{array}$ & 5 & 6 & 32 & 11 & 5 & 4 & 63 \\
\hline $\begin{array}{l}\text { Number of SLIP-HPCs: } \\
\text { number of different } \\
\text { parasite species Ratio }\end{array}$ & 1 & 2.33 & 1.06 & 2.54 & 4.2 & 1.5 & 1.71 \\
\hline $\begin{array}{l}\text { Number of different } \\
\text { parasite species:number } \\
\text { of fish species Ratio }\end{array}$ & 0.36 & 0.42 & 2.29 & 0.79 & 0.36 & 0.29 & 4.5 \\
\hline
\end{tabular}

city. We hypothesise above that probably all serranids harbour all of the four major species, so an exhaustive search would probably find an even higher ratio. Monogeneans, with 34 combinations and 32 species (1.06 combinations per species) exemplify a parasite group which is known to display strong host specificity. Additional cases are found in the other groups. Copepods have 14 combinations and six species, but when the different Hatschekia species are described, will show a very much lower number of combinations per species. The SLIP-HPCs:parasite species ratio calculated from Table 4 for all groups is $1.71(109 / 63)$ which means that parasite species are generally found in more than one host.

\section{An attempted prediction of parasite biodiversity in groupers}

Our data include fish with various sample sizes (from 1 to more than one hundred). Table 5 shows that the numbers of HPCs, SLIP-HPCs and different parasite species increase with the quality of sampling. The most extensively sampled fish had 17.9 HPCs / fish species, 9.0 SLIP-HPCs / fish species and the number of different parasite species was 6.3 / fish species. This latter number was computed from Appendix 1 and counts only once the parasite species found in several fish: it is thus an estimate of the total parasite biodiversity.

However, we have seen above that this number is an underestimate because many parasite species are yet undescribed and because several groups were not identified 
Table 5. Effect of fish sampling on the number of parasites found. Number of HPCs and SLIP-HPCs are from Table 1; number of different parasite species computed from Appendix 1.

\begin{tabular}{|c|c|c|c|c|c|c|c|c|}
\hline $\begin{array}{l}\text { Sampled fish } \\
\text { number }\end{array}$ & $\mathrm{n}$ & $\begin{array}{c}\text { Total fish } \\
\text { number }\end{array}$ & HPCs & $\begin{array}{l}\text { HPCs per } \\
\text { fish species }\end{array}$ & $\begin{array}{l}\text { SLIP- } \\
\text { HPCs }\end{array}$ & $\begin{array}{c}\text { SLIP-HPCs } \\
\text { per fish species }\end{array}$ & $\begin{array}{l}\text { Parasite } \\
\text { species }\end{array}$ & $\begin{array}{l}\text { Parasite species } \\
\text { per fish species }\end{array}$ \\
\hline $\mathrm{n}<5$ & 11 & 25 & 91 & 8.27 & 29 & 2.64 & 23 & 2.09 \\
\hline $\mathrm{n}=5-29$ & 10 & 124 & 121 & 12.10 & 54 & 5.40 & 41 & 4.10 \\
\hline $\mathrm{n}>29$ & 7 & 391 & 125 & 17.86 & 63 & 9.00 & 44 & 6.29 \\
\hline All fish & 28 & 540 & 337 & 12.04 & 146 & 5.21 & 76 & 2.71 \\
\hline
\end{tabular}

Table 6. Predictions of biodiversity in serranids.

\begin{tabular}{lccccc}
\hline & $\begin{array}{c}\text { All 28 ser- } \\
\text { ranids / fish }\end{array}$ & $\begin{array}{c}7 \text { species with } \\
\text { n>9 / fish }\end{array}$ & $\begin{array}{c}\text { Prediction } \\
\text { / fish }\end{array}$ & $\begin{array}{c}\text { Prediction, all 41 groupers } \\
\text { of New Caledonia }\end{array}$ & $\begin{array}{c}\text { Prediction, all 159 } \\
\text { groupers of the World }\end{array}$ \\
\hline HPCs & 12 & 17.9 & 30 & 1230 & 4770 \\
Different parasite species & 2.7 & 6.3 & 10 & 410 & 1590 \\
\hline
\end{tabular}

Table 7. Size of selected fish and number of parasite species. Fish lengths according to Kulbicki et al. (2005).

\begin{tabular}{lccc}
\hline Fish & Maximum length & $\begin{array}{c}\text { Number of host- } \\
\text { parasite combinations }\end{array}$ & $\begin{array}{c}\text { Number of parasite species } \\
\text { (identified at species level) }\end{array}$ \\
\hline Small species & & & \\
Ep. merra & 25 & 9 & 4 \\
$\quad$ Ep. fasciatus & 36 & 21 & 10 \\
Large species & & 36 & 19 \\
Ep. maculatus & 60 & 31 & 20 \\
Ep. cyanopodus & 76 & & \\
\hline
\end{tabular}

at the species level. Also, for six of the seven fish species with the maximum sampling effort $(n>29)$, the number of fish examined for gills and/or for abdominal organs was below 29 and thus these fish certainly cannot be considered as well sampled. Thus, in Table 6, we propose to predict parasite biodiversity in serranids by multiplying the results obtained by approximately 2 . Predictions are 30 HPCs and 10 different parasite species per fish, thus 1230 HPCs and 410 different parasites species for all the 41 groupers of New Caledonia.

Epinephelus fasciatus has been reasonably well sampled $(\mathrm{n}=92)$ and has 10 parasite species identified at the species level (Table 1), but several of these species are found in other fish. Again, this number of 10 is an underestimate because of the several parasite groups in which species were not identified with precision or there were other limitations (stated above). We consider that the case of Ep. fasciatus is exemplary of the serranids, and confirms our prediction of 10 different parasite species per serranid species.

Monogeneans constitute a major part of the parasite biodiversity encountered. In Table 4, monogeneans constitute half of the SLIPs $(32: 63)$. For the seven best sampled fish $(n>29)$, there are 18 monogeneans among the 44 SLIPs $(40 \%)$. This is certainly of significance, because it is known that monogeneans show high biodiversity and generally strict host specificity (Euzet and Combes 1980). The monogeneans identified to species-level of the seven best sampled fish show a ratio of 2.57 monogeneans per fish (18:7). Although impressive, this ratio falls below other published estimates of 3:1 (Lim 1998) and 5:1 (Whittington 1998). Appendix 1 shows that about half a dozen undescribed monogenean species are present in these seven 'well sampled' fish species, and additional monogenean species could certainly be found in 'neglected' organs such as branchiostegal membranes and fins. We may thus estimate that only half of the true monogenean biodiversity has been found, and that a ratio of five monogenean species per serranid should be expected. To fully document all monogeneans would require a significant effort both in sampling and in descriptive taxonomy, because most of the species are new to science.

\section{An attempted prediction of parasite biodiversity in other fish of the Lagoon}

Our results on serranids can be extrapolated to all fish families, but with some precautions. Parasite biodiversity can differ in other fish families because of different body sizes and because of phylogenetic or ecological differences.

In Table 7, we compared the number of parasite species on a small subset of our results, limited to fish species with a significant sample size ( $\mathrm{n}>29$ for both gills and abdominal organs except Ep. cyanopodus, $\mathrm{n}=22$ ) and in which the monogeneans have been extensively described. This analysis shows that large fish have more parasite species than small fish, as expected (Luque and Poulin 2007). Ep. fasciatus (maximum length $36 \mathrm{~cm}$ ) has a mean length similar to the mean length of ca. 400 species of lagoon fishes of New Caledonia (Kulbicki et al. 2005). Therefore 
Table 8. Available references on the parasites of serranids in the Indo-Pacific Region.

\begin{tabular}{|c|c|c|c|c|c|}
\hline Reference & Parasite groups & Locality & $\begin{array}{l}\text { Number of serranid } \\
\text { species mentioned }\end{array}$ & $\begin{array}{l}\text { Number of serranid } \\
\text { species in common } \\
\text { with the present study }\end{array}$ & $\begin{array}{l}\text { Number of parasites } \\
\text { mentioned in } \\
\text { these species }\end{array}$ \\
\hline Zhang et al. 2003 & Monogeneans & China & ca. 11 & 4 & 4 \\
\hline Rigby et al. 1999 & all & French Polynesia & 2 & 4 & 13 \\
\hline Yang 2007 & Cestodes & China & 0 & 0 & 0 \\
\hline Arthur and Te 2006 & all & Viet Nam & 4 & 1 & 1 \\
\hline Arthur and Lumanlan-Mayo 1997 & all & Philippines & 5 & 3 & 7 \\
\hline Arthur and Ahmed 2002 & all & Bangladesh & 0 & 0 & 0 \\
\hline Yamaguti 1968 & Monogeneans & Hawaii & 1 & 0 & 0 \\
\hline Yamaguti 1970 & Digeneans & Hawaii & 2 & 0 & 0 \\
\hline Beumer et al. 1983 & all & Australia & 8 & 4 & 15 \\
\hline Lester and Sewell 1989 & all & $\begin{array}{l}\text { Heron Island, Queensland, } \\
\text { Australia }\end{array}$ & 10 & 5 & 54 \\
\hline
\end{tabular}

it is reasonable to consider that the results found for this fish (10 parasite species per fish species) could be extrapolated to all fish of the lagoon (but see below for limits).

Other fish families of the lagoon of New Caledonia have not been sampled as extensively as the serranids. However, we already know examples of parasite biodiversity in other families that are similar to that of serranids, such as digeneans of balistids (Bray and Justine 2006b, 2007, Bray et al. 2009a, b), monogeneans of lutjanids (Kritsky et al. 2009), monogeneans (Justine 2007d, Rascalou and Justine 2007, Justine et Briand 2010) and nematodes (Moravec and Justine 2010) of lethrinids, and monogeneans (К̌ehulková et al. 2010) and digeneans (Bray and Justine 2008) of mullids. Because monogeneans often constitute a major part of parasite biodiversity, families with few monogeneans could significantly decrease parasite biodiversity: this could be expected for the labrids (Lim and Justine 2007, Munoz et al. 2007) or gobiids. It might be also that carnivorous fish such as labrids have increased opportunities to obtain parasites than fish with other diets. However, our prediction of 10 parasite species per fish being minimal, we believe that several families with higher parasite biodiversity would compensate for families with lower diversity. For the ca. 1,700 fish species in the lagoon of New Caledonia (Fricke and Kulbicki 2007), we may thus predict about 17,000 different parasite species and 2-3 times more (34,000-51,000) host-parasite combinations.

To obtain these predicted numbers, a tremendous sampling effort would be necessary. At least 30 specimens would have to be examined for each fish species, and the number of individual parasites examined would be enormous. This is simply another manifestation of the taxonomic impediment. These figures include only metazoans (helminths and parasitic crustaceans), but it is likely that microscopic protistan and myxozoan parasites would greatly increase these numbers: for example, the examination of five serranid species from the Great Barrier Reef has revealed seven species of ceratomyxid myxozoans (Gunter and Adlard 2009).
On the basis of simple calculations mainly based on monogenean diversity, a prediction of 20,000 parasite species (including metazoans and protozoans) has been made for the 1,000 fish species of Heron Island in the Great Barrier Reef (Rohde 1976). Our prediction is similar to Rohde's estimate, taking into account the proportion of microscopic parasites present.

New Caledonia exemplifies the need for taxonomic studies on fish parasites. A compilation of 107 publications provided a list of 371 species of fish parasites in New Caledonia (Justine 2010), which does not include the newly published serranid parasites of the present paper. This means that about 2\% (370:17,000) of the total predicted fish parasite biodiversity has been recorded so far. For the evaluation of tropical forest biodiversity, and without targeting parasite groups, a major problem is that "the proportion of 'morphospecies' that cannot be assigned to identified species and the number of 'scientist-hours' required to process samples both increase dramatically for smaller-bodied taxa" (Lawton et al. 1998). This situation applies perfectly to the parasites of coral reef fishes.

\section{An attempt at biogeographical comparison}

The availability of these numerically important data on the biodiversity of parasites of serranids in New Caledonia should allow us to make comparisons with the parasitic faunas of the same fish species in other locations. Most of the serranid species mentioned in this study have a wide geographical distribution (Heemstra and Randall 1993, Froese and Pauly 2009) and it might be expected that we would find copious records of their parasitic fauna. To our great disappointment, we found very few similarly comprehensive studies in the literature.

Several studies investigated the fauna of monogeneans on various coral reefs of the Indo-Pacific, but these have been restricted to a few genera (Plaisance et al. 2005,2008 ) or a few species (Justine 2005a, Marie and Justine 2006, Justine et al. 2009a); a few digeneans have also been compared in various locations (Lo et al. 2001). A few studies have used more than one parasite group, but on the basis of vague comparison (Williams et al. 1996) 
Table 9. Cromileptes altivelis: comparison of its parasitic fauna in Heron Island (HI) (Lester and Sewell 1989) and New Caledonia (NC) (present study).

\begin{tabular}{|c|c|c|}
\hline Cromileptes altivelis & $\mathrm{HI}$ & $\mathrm{NC}$ \\
\hline Isop: Aegi: Aega lethrina & + & \\
\hline Isop: Cora: Argathona macronema & + & \\
\hline Cope: Cali: Dentigryps litus & + & \\
\hline Cope: Siph: Larvae & & + \\
\hline Mono: Ancy: Haliotrema cromileptis & + & + \\
\hline Dige: Acan: Mitotrema acanthostomatum & + & \\
\hline Dige: Buce: Prosorhynchus sp. & + & \\
\hline Nema: Anis: Unidentified larvae & & + \\
\hline Total: 8,1 in common including 1 identified at species level & 6 & 3 \\
\hline
\end{tabular}

Table 10. Epinephelus fasciatus: comparison of its parasitic fauna in Heron Island (HI) (Lester and Sewell 1989) and New Caledonia (NC) (present study).

\begin{tabular}{|c|c|c|}
\hline Epinephelus fasciatus & & $\mathrm{NC}$ \\
\hline Cope: Phil: Colobomatus sp. & + & \\
\hline Cope: Cali: Caligus n. sp. & & + \\
\hline Cope: Hats: Hatschekia sp. (n. sp. 1 in NC) & + & + \\
\hline Mono: Caps: Benedenia cf. epinepheli & & + \\
\hline Mono: Dipl: Pseudorhabdosynochus youngi ${ }^{*}$ & + & + \\
\hline Mono: Dipl: Pseudorhabdosynochus caledonicus & & + \\
\hline Mono: Ancy: Haliotrema epinepheli & + & \\
\hline Cest: Scolex polymorphus & + & \\
\hline Dige: Bive: Bivesicula sp. & & + \\
\hline Dige: Didy: Unidentified adults & & + \\
\hline Dige: Didy: Unidentified larvae & & + \\
\hline Dige: Gorg: Phyllodistomum sp. & & + \\
\hline Dige: Hemi: Lecithochirium sp. & & + \\
\hline Dige: Lepo: Lepidapedoides angustus & & + \\
\hline Dige: Opec: Allopodocotyle epinepheli & & + \\
\hline Dige: Opec: Cainocreadium epinepheli & & + \\
\hline Dige: Opec: Helicometra epinepheli & & + \\
\hline Tetra: Unid: Larvae & + & + \\
\hline Tryp: Laci: Pseudolacistorhynchus heroniensis & & + \\
\hline Tryp: Pseu: Pseudotobothrium dipsacum & & + \\
\hline Nema: Anis: Terranova sp. & + & \\
\hline Nema: Anis: Unidentified & & + \\
\hline Nema: Cama: Procamallanus variolae & & + \\
\hline Nema: Philo: Philometra fasciati & & + \\
\hline Turbellaria: Unid: Unidentified species & & + \\
\hline $\begin{array}{l}\text { Total: } 25 ; 3 \text { in common, including } 1 \text { identified at species level; } \\
\text { * as Diplectanum cupatum in HI (Justine et al. 2009a) }\end{array}$ & 7 & 21 \\
\hline
\end{tabular}

or with a very low level of parasite identification (Lafferty et al. 2008). Apparently no study has compared significant lists of parasites from several groups with a sufficient level of parasite taxonomic accuracy in several locations.

Table 8 lists general surveys of fish parasites available for the Indo-Pacific. Only helminths and parasitic crustaceans are included. Most studies have only a very small number of serranid species and parasites in common with our study. The study by Rigby et al. (1999) apparently has more potentially comparable data, but the lack of precision of the parasite identifications makes it of little value. Finally, significant and reliable data are available only in the general list of Lester and Sewell (1989) for Heron Is-
Table 11. Epinephelus malabaricus: comparison of its parasitic fauna in Heron Island (HI) (Lester and Sewell 1989) and New Caledonia (NC) (present study).

\begin{tabular}{lr}
\hline Epinephelus malabaricus & HI NC \\
\hline Isop: Cora: Argathona rhinoceros & + \\
Cope: Hats: Hatschekia n. sp. 6 & + \\
Cope: Cali: Lepeophtheirus plectropomi & + \\
Cope: Siph: Chalimus larvae & + \\
Mono: Ancy: Haliotrema sp. 1 & + \\
Mono: Ancy: Haliotrema sp. 2 & + \\
Mono: Ancy: Unidentified species* & + \\
Mono: Caps: Allosprostonia tauvinae & + \\
Mono: Caps: Allobenedenia sp. & + \\
Mono: Caps: Sprostonia longiphallus*** & + \\
Mono: Dipl: Diplectanum maa & + \\
Mono: Dipl: Pseudorhabdosynochus cf. shenzhenensis & + \\
Mono: Dipl: Pseudorhabdosynochus maaensis & + \\
Mono: Dipl: Pseudorhabdosynochus malabaricus & + \\
Mono: Dipl: Pseudorhabdosynochus manifestus & + \\
Mono: Dipl: Pseudorhabdosynochus manipulus & + \\
Mono: Dipl: Pseudorhabdosynochus marcellus & + \\
Mono: Dipl: Pseudorhabdosynochus maternus & + \\
Mono: Dipl: Unidentified 6 species** & + \\
Dige: Buce: Prosorhynchus maternus & + \\
Dige: Opec: Cainocreadium sp. & + \\
Tryp: Laci: Pseudogilquinia pillersi & + \\
Tryp: Pseu: Pseudotobothrium dipsacum & + \\
Nema: Anis: Terranova sp. & + \\
Nema: Unidentified species & + \\
\hline Total: 25; 0 in common, but possibly several ancyrocephalids* & 5 \\
and diplectanids** in common but not specifically identified in & + \\
HI; *** dubious record because the type-species of Sprostonia & \\
occurs on an elasmobranch (Whittington 2004). In addition, & \\
both capsalids in the list from HI are not mentioned from this & \\
host in the original publication cited. & \\
\hline & + \\
\hline
\end{tabular}

land (Queensland), on the Great Barrier Reef. This study has the additional interest of being limited to a small geographical area, as is our study.

Five species of groupers were shared by the Heron Island (HI) list and our work in New Caledonia (NC). Tables 9-13 summarise the parasite species found on $\mathrm{HI}$ and in NC for these five fish species. An interesting case is $E p$. merra. Of 16 parasite records, including 7 on $\mathrm{HI}$ and 9 in $\mathrm{NC}$, none was found in common (Table 13). 'Detective work' on Museum slides deposited by P. C. Young in collections (Justine et al. 2009a) lead to the conclusion that the fish designated as Ep. merra in parasitological works by Young was probably Ep. quoyanus. It is therefore not surprising that no parasite was found in common between two different fish species; this work exemplifies the need for deposition of parasite, and even fish, specimens, tissue samples and digital images. Finally, after excluding Ep. merra, only four species of fish could be compared for their parasitic fauna between HI and NC (Table 14). In total these fish had 91 parasite records (37 on $\mathrm{HI}$ and 65 in NC). Including imprecise identifications only nine records were shared. Shared records with identifications at the species level were only six ( $7 \%$ of all records). These include one isopod, the corallanid Argathona macronema in Pl. leopardus; one copepod, the hatschekiid Hatschekia 
Table 12. Plectropomus leopardus: comparison of its parasitic fauna in Heron Island (HI) (Lester and Sewell 1989) and New Caledonia (NC) (present study).

\begin{tabular}{|c|c|c|}
\hline Plectropomus leopardus & $\mathrm{HI}$ & $\mathrm{NC}$ \\
\hline Isop: Aegi: Aega lethrina & + & \\
\hline Isop: Cora: Argathona macronema & + & + \\
\hline Isop: Cora: Argathona rhinoceros & & + \\
\hline Cope: Cali: Dentigryps sp. & + & \\
\hline Cope: Cali: Lepeophtheirus sp. & & + \\
\hline Cope: Diss: Dissonus manteri & & + \\
\hline Cope: Diss: Unidentified species & + & \\
\hline Cope: Hats: Hatschekia plectropomi & + & + \\
\hline Cope: Lern: Sagum epinepheli & & + \\
\hline Cope: Penn: Larvae & & + \\
\hline Mono: Ancy: Unidentified species & + & \\
\hline Mono: Caps: Trochopus sp. & + & \\
\hline Mono: Caps: Trochopodinae sp. 2 of Perkins et al. (2009) & & + \\
\hline Mono: Dipl: Echinoplectanum leopardi & & + \\
\hline Mono: Dipl: Echinoplectanum pudicum & & + \\
\hline Mono: Dipl: Echinoplectanum rarum & & + \\
\hline Mono: Dipl: Unidentified species & + & \\
\hline Dige: Bive: Unidentified species & + & \\
\hline Dige: Buce: Prosorhynchus sp. & + & + \\
\hline Dige: Buce: Neidhartia sp. 1 & & + \\
\hline Dige: Buce: Neidhartia sp. 2 & & + \\
\hline Dige: Didy: Unidentified species & + & \\
\hline Dige: Hemi: Unidentified & + & \\
\hline Dige: Opec: Pacificreadium serrani & + & + \\
\hline Dige: Apor: Pearsonellum corventum & + & \\
\hline Tetra: Unid: Unidentified species & + & + \\
\hline Tryp: Laci: Pseudogilquinia pillersi & & + \\
\hline Tryp: Laci: Floriceps minacanthus & + & + \\
\hline Tryp: Pseu: Pseudotobothrium dipsacum & & + \\
\hline Tryp: Unid: Unidentified species & + & \\
\hline Nema: Anis: Hysterothylacium sp. & + & \\
\hline Nema: Anis: Terranova sp. & + & \\
\hline Nema: Capi: Unidentified species & & + \\
\hline $\begin{array}{l}\text { Comments: Total: } 33 ; 5 \text { in common, including } 4 \text { identified at } \\
\text { the species level }\end{array}$ & 19 & 20 \\
\hline
\end{tabular}

plectropomi in $\mathrm{Pl}$. leopardus; two monogeneans, the ancyrocephalid Haliotrema cromileptis in Cromileptes altivelis and the diplectanid Pseudorhabdosynochus youngi in Ep. fasciatus; one digenean, the opecoelid Pacificreadium serrani in $\mathrm{Pl}$. leopardus; and one larval trypanorhynch cestode, Floriceps minacanthus.

Only limited comparisons can be made between the trypanorhynch species found in New Caledonia and those reported from Heron Island by Lester and Sewell (1989) and Palm (2004). All five species occur around Heron Island and all except $C$. gracilis and $P$. pillersi have been found in serranids (Ep. ongus, Ep. quoyanus, Pl. leopardus, Pl. maculatus). There are numerous records of C. gracilis from teleosts from the north-east coast of Australia (Palm 2004), though none is from serranids, while $P$. pillersi has been reported from lethrinids off Heron Island (Beveridge et al. 2007). More extensive collecting of serranids at Heron Island is likely to confirm the presence of all of these trypanorhynch species in this host group.
Table 13. Epinephelus merra: comparison of its parasitic fauna in Heron Island (HI) (Lester and Sewell 1989) and New Caledonia (NC) (present study). Discrepancies suggest that the host was misidentified in Heron Island (see text).

\begin{tabular}{lcc}
\hline Epinephelus merra & HI NC \\
\hline Cope: Cali: Caligus epinepheli & + & \\
Cope: Cali: Lepeophtheirus sp. & + \\
Cope: Lern: Sagum epinepheli & & + \\
Cope: Lerp: Alella pterobrachiata & + & \\
Cope: Lerp: Anaclavella sillaginoides & + & \\
Cope: Lerp: Thysanote gymnobrachiata & + & \\
Cope: Penn: Larvae & & + \\
Cope: Siph: Larvae & & + \\
Mono: Dipl: Pseudorhabdosynochus melanesiensis & & + \\
Mono: Dipl: Pseudorhabdosynochus cf. coioidesis & & + \\
Mono: Caps: Unidentified Benedeniinae & & + \\
Dige: Opec: Allopodocotyle epinepheli & & + \\
Dige: Opec: Cainocreadium epinepheli & + & \\
Dige: Opec: Helicometra epinepheli & & + \\
Dige: Opec: Helicometra fasciata & + & \\
Dige: Apor: Pearsonellum corventum & + & \\
Comments: Total: 16, 0 in common & 7 & 9 \\
\hline
\end{tabular}

Table 14. Summary of all comparisons in Tables $9-13$ between serranids of Heron Island (HI) and New Caledonia (NC). Epinephelus merra is excluded because of fish misidentification in HI (Justine et al. 2009a).

\begin{tabular}{|c|c|c|c|c|c|}
\hline Fish & HI & $\mathrm{NC}$ & $\begin{array}{l}\text { Total } \\
\text { of re- } \\
\text { cords }\end{array}$ & $\begin{array}{l}\text { Records in common } \\
\text { (including imprecise } \\
\text { identifications) }\end{array}$ & $\begin{array}{l}\text { Records in common } \\
\text { (with identification } \\
\text { at species level) }\end{array}$ \\
\hline $\begin{array}{l}\text { Cromileptes } \\
\text { altivelis }\end{array}$ & 6 & 3 & 8 & 1 & 1 \\
\hline $\begin{array}{l}\text { Epinephelus } \\
\text { fasciatus }\end{array}$ & 7 & 21 & 25 & 3 & 1 \\
\hline $\begin{array}{l}\text { Plectropomus } \\
\text { leopardus }\end{array}$ & 19 & 20 & 33 & 5 & 4 \\
\hline $\begin{array}{l}\text { Epinephelus } \\
\text { malabaricus }\end{array}$ & 5 & 20 & 25 & 0 & 0 \\
\hline Total & 37 & 65 & 91 & (10\% of all records) & (7\% of all records) \\
\hline
\end{tabular}

From the prediction of the parasite fauna attempted above, we would expect 10 parasite species per fish, i.e. a total of 40 species for the four fish involved. Table 14 includes 91 records, but this does not indicate that biodiversity has been sampled accurately; indeed, many records are duplicated in both locations because of insufficient precision in species identification. As an example, for $P l$. leopardus, we do not know if the 'unidentified Dissonidae' found on HI is the same as Dissonus manteri found in $\mathrm{NC}$, and currently we are forced to regard these two records as separate taxa.

Reliable comparisons should be made only on parasites identified at the species level, and there are only six of these from the four species of fish (Table 14). It is difficult to interpret these results from a biogeographical perspective. We consider that the very small number of species in common does not reflect differences in the parasite fauna but rather shows that sampling was inadequate at both locations. The taxonomic impediment strikes again here, 
making it practically impossible to compare the parasite faunas of the serranids in these two locations. Again, the limitation of 'scientist-hours' for small-bodied organisms (Lawton et al. 1998) is obvious.

Acknowledgements. The authors are in alphabetical orders, except for the first one. Julie Mounier, Charles Beaufrère, Anaïs Guillou, Audrey Guérin, Damien Hinsinger, Éric Bureau, Chloé Journo, Violette Justine, Amandine Marie, Aude Sigura, Guilhem Rascalou, Géraldine Colli, Lenaïg Hemery, Pierpaolo Brena, Cyndie Dupoux, Isabelle Mary, Adeline Grugeaud, and Marine Briand, students, participated in the parasitological survey. Claude Chauvet (UNC, Nouméa) caught several fishes. Angelo di Matteo (IRD) provided technical help. Certain fishes were identified from photographs by Ronald Fricke (Staatliches Museum für Naturkunde, Stuttgart, Germany) or by Jack Randall (Bishop Museum, Hawai'i). Partly supported by Australian Research Council grant No. DP0556780 (2005-07) awarded to IDW and Steve Donnellan (South Australian Museum) and research projects of the Institute of Parasitology, BC ASCR (Z60220518 and LC522) awarded to FM.

\section{Appendix 1: Host-parasite list (28 fish species)}

For brevity, all references are numbered according to this list: [0] This paper; [1] Beveridge et al. 2007; [2] Boxshall et al. 2008; [3] Bray and Justine 2006a; [4] Bray and Justine 2006b; [5] Bray and Justine 2007; [6] Hinsinger and Justine 2006a; [7] Hinsinger and Justine 2006b; [8] Journo and Justine 2006; [9] Justine 2005a; [10] Justine 2005b; [11] Justine 2007b; [12] Justine 2007c; [13] Justine 2008a; [14] Justine 2008c; [15] Justine 2008b; [16] Justine 2009; [17] Justine et al. 2009a; [18] Justine and Euzet 2006; [19] Justine et al. 2009b; [20] Justine and Sigura 2007; [21] Kuchta et al. 2009a; [22] Moravec and Justine 2005; [23] Moravec and Justine 2008; [24] Moravec and Justine 2009; [25] Moravec et al. 2006; [26] Sigura et al. 2007; [27] Sigura and Justine 2008.

The serranid hosts of digenean species described by Manter were often very vaguely designated as 'leche' (Justine 2007a). New Host Records for these species are indicated as NHR*

\section{Anyperodon leucogrammicus (Valenciennes, 1828)}

Cope: Siph: larvae (gills) [0]

Mono: Dipl: Pseudorhabdosynochus n. sp. 1 (gills) [0] Mono: Dipl: Pseudorhabdosynochus n. sp. 2 (gills) [0]

Remarks: Based on examination of 3 specimens ( 2 for gills, 1 for abdominal organs).

Host-parasite combinations: 3; with species-level identification: 0 .

\section{Cephalopholis hybrid: aurantia $\times$ spiloparaea}

Cope: Siph: larvae (gills) [0]

Both: Both: Bothriocephalus celineae Kuchta, Scholz et Justine, 2009 (digestive tract) [21]

Remarks: Based on examination of single specimen (1 for gills, 1 for abdominal organs)

Host-parasite combinations: 2; with species-level identification: 1 .

Reference for hybrid fish: Randall and Justine 2008.

Cephalopholis argus Bloch et Schneider, 1801

Isop: Gnat: Praniza larvae (gills) [0]

Mono: Dipl: Pseudorhabdosynochus argus Justine, 2007 (gills) [12]

Mono: Caps: unidentified (gills) [0]

Dige: Buce: Prosorhynchus robertsthomsoni Bott et Cribb, 2009 (digestive tract) [0] (NGR)

Nema: Anis: unidentified larvae (digestive tract) [0]

Remarks: Based on examination of 5 specimens ( 4 for gills, 3 for abdominal organs).

Host-parasite combinations: 5; with species-level identification: 2.
Cephalopholis boenak (Bloch, 1790)

Isop: Gnat: Praniza larvae (gills) [0]

Isop: Cora: Lanocira zeylanica Stebbing, 1905 (body) [0] (NHR)

Dige: Bive: Bivesicula claviformis Yamaguti, 1934 (digestive tract) [0] (NHR)

Tetr: Unid: larvae (digestive tract) [0]

Tryp: Laci: Callitetrarhynchus gracilis (Rudolphi, 1819) larvae (body cavity) [0] (NHR)

Tryp: Laci: Pseudolacistorhynchus heroniensis (Sakanari, 1989) larvae (body cavity) [0] (NHR)

Nema: Anis: unidentified larvae (digestive tract) [0]

Remarks: Based on examination of 59 specimens (42 for gills, 18 for abdominal organs); absence of gill monogeneans confirmed on 42 specimens.

Host-parasite combinations: 7; with species-level identification: 4.

Cephalopholis miniata (Forsskål, 1775)

Mono: Caps: unidentified Benedeniinae 1 (branchiostegal membranes) [0]

Mono: Caps: unidentified Benedeniinae 2 (gills) [0]

Mono: Caps: unidentified Benedeniinae 3 (gills) [0]

Mono: Dipl: Diplectanum sp. (gills) [0]

Dige: Didy: unidentified adult (gills) [0]

Dige: Opec: Cainocreadium epinepheli (Yamaguti, 1934) (digestive tract) [0]

Tetr: Unid: larvae (digestive tract) [0]

Tryp: Laci: Floriceps minacanthus Campbell et Beveridge, 1987 larvae (body cavity) [0] (NHR)

Tryp: Pseu: Pseudotobothrium dipsacum (Linton, 1897) larvae (body cavity) [0] (NHR)

Nema: Anis: unidentified larvae (digestive tract) [0]

Remarks: Based on examination of 3 specimens (3 for gills, 3 for abdominal organs)

Host-parasite combinations: 10; with species-level identification: 3.

Cephalopholis sonnerati (Valenciennes, 1828)

Cope: Penn: larvae (gills) [0]

Mono: Ancy: Haliotrema sp. of Justine 2007 (gills) [12]

Mono: Caps: unidentified Benedeniinae (gills) [0]

Mono: Dipl: Diplectanum nanus Justine, 2007 (gills) [12]

Mono: Dipl: Pseudorhabdosynochus minutus Justine, 2007 (gills) [12]

Tetr: Unid: larvae (digestive tract) $[0]$

Tryp: Pseu: Pseudotobothrium dipsacum larvae (body cavity) [0] (NGR)

Nema: Anis: unidentified larvae (digestive tract) [0]

Remarks: Based on examination of 8 specimens ( 7 for gills, 5 for abdominal organs).

Host-parasite combinations: 8; with species-level identification: 3 .

Cephalopholis spiloparaea (Valenciennes, 1828)

Cope: Siph: larvae (gills) [0]

Tetr: Unid: larvae (digestive tract) [0]

Tryp: Unid: larvae (body cavity) [0]

Remarks: Based on examination of 2 specimens ( 1 for gills, 2 for abdominal organs).

Host-parasite combinations: 3; with species-level identification: 0 .

Cephalopholis urodeta (Schneider, 1801)

Isop: Gnat: Praniza larvae (gills) [0]

Cope: Penn: larvae (gills) [0]

Mono: Caps: unidentified species (body) [0]

Mono: Dipl: Diplectanum parvus Justine, 2008 (gills) [13]

Dige: Acan: Stephanostomum japonocasum Durio et Manter, 1969 (digestive tract) [0]

Dige: Buce: Prosorhynchus sp. (digestive tract) [0]

Dige: Opec: Helicometra sp. (digestive tract) [0]

Dige: Opec: Cainocreadium epinepheli (digestive tract) [0]

Tetr: Unid: larvae (digestive tract) [0] 
Tryp: Laci: Floriceps minacanthus larvae (body cavity) [0] (NHR)

Tryp: Pseu: Pseudotobothrium dipsacum larvae (body cavity) [0] (NHR)

Nema: Anis: unidentified larvae (digestive tract) [0]

Remarks: Based on examination of 38 specimens (32 for gills, 19 for abdominal organs)

Host-parasite combinations: 12; with species-level identification: 5.

Cromileptes altivelis (Valenciennes, 1828)

Cope: Siph: larvae (gills) [0]

Mono: Ancy: Haliotrema cf. cromileptis (gills) [0]

Nema: Anis: unidentified larvae (digestive tract) [0]

Remarks: Based on the examination of 4 specimens ( 4 for gills, 2 for abdominal organs).

Host-parasite combinations: 3 ; with species-level identification: 0 .

\section{Epinephelus areolatus (Forsskål, 1775)}

Isop: Gnat: Praniza larvae (gills) [0]

Mono: Caps: unidentified immature (gills) [0]

Mono: Dipl: Pseudorhabdosynochus sp. (gills) [0]

Mono: Dipl: Diplectanum sp. (gills) [0]

Dige: Buce: Prosorhynchus longisaccatus Durio et Manter, 1968 (digestive tract) [0] (NHR*)

Dige: Acan: Stephanostomum japonocasum (digestive tract) [0]

Dige: Opec: Allopodocotyle sp. (digestive tract) [0]

Tetr: Unid: larvae (digestive tract) [0]

Nema: Anis: Terranova sp. larvae

Nema: Anis: Anisakis sp. larvae

Nema: Philo: Philometra ocularis Moravec, Ogawa, Suzuki, Miyazaki et Donai, 2002 (orbits) [23][24]

Remarks: Based on examination of 14 specimens ( 9 for gills, 12 for abdominal organs).

Host-parasite combinations: 11; with species-level identification: 3 .

Epinephelus chlorostigma (Valenciennes, 1828)

Cope: Hats: Hatschekia n. sp. 2 (gills) [0]

Cope: Lern: Sagum epinepheli (Yamaguti et Yamasu, 1960) (gills) [0] (NHR)

Mono: Caps: Allobenedenia $\mathrm{cf}$. epinepheli (Bychowsky et Nagibina, 1967) (gills) [0]

Mono: Dipl: Pseudorhabdosynochus epinepheli (Yamaguti, 1938) (gills) [16]

Mono: Dipl: Pseudorhabdosynochus n. sp. 1 (gills) [0]

Mono: Dipl: Diplectanum n. sp. (gills) [0]

Mono: Ancy: Haliotrema sp. (gills) [0]

Dige: Didy: unidentified adult (fins) [0]

Dige: Hemi: Lecithochirium sp. (digestive tract) [0]

Dige: Buce: Prosorhynchus sp. (digestive tract) [0]

Dige: Acan: Stephanostomum japonocasum (digestive tract) [0]

Dige: Bive: Bivesicula sp. (digestive tract) [0]

Tetr: Unid: larvae (digestive tract) [0]

Tryp: Laci: Pseudolacistorhynchus heroniensis larvae (body cavity) [0] (NHR)

Tryp: Laci: Callitetrarhynchus gracilis (Rudolphi, 1819) larvae (body cavity) [0] (NHR)

Nema: Anis: unidentified larvae (digestive tract) [0]

Remarks: Based on examination of single specimen ( 1 for gills, 1 for abdominal organs).

Host-parasite combinations: 16; with species-level identification: 5.

Epinephelus coeruleopunctatus (Bloch, 1790)

Cope: Lern: Sagum epinepheli (gills) [0] (NHR)

Cope: Hats: Hatschekia n. sp. 1 (gills) [0]

Cope: Cali: Lepeophtheirus epinepheli Ho et Dojiri, 1977 (Skin) [0] (NHR)

Mono: Dipl: Pseudorhabdosynochus bacchus Sigura, Chauvet et Justine, 2007 (gills) [26]

Mono: Dipl: Pseudorhabdosynochus n. sp. 1 (gills) [26]

Mono: Dipl: Pseudorhabdosynochus n. sp. 2 (gills) [26]

Mono: Ancy: Haliotrema sp. (gills) [26]
Dige: Buce: Prosorhynchus sp. immature (digestive tract) [0]

Dige: Dero: Derogenes-like sp. (digestive tract) [0]

Dige: Opec: Cainocreadium epinepheli (digestive tract) [5]

Remarks: Based on examination of 7 specimens ( 5 for gills, 5 for abdominal organs).

Host-parasite combinations: 10; with species-level identification: 4.

Epinephelus coioides (Hamilton, 1822)

Isop: Cora: Argathona rhinoceros (Bleeker, 1857) (nasal cavities) [0] (NHR)

Mono: Caps: Allobenedenia cf. epinepheli (gills) [0]

Mono: Dipl: Pseudorhabdosynochus sp. 1 (gills) [0]

Mono: Dipl: Pseudorhabdosynochus sp. 2 (gills) [0]

Mono: Dipl: Pseudorhabdosynochus sp. 3 (gills) [0]

Mono: Dipl: Pseudorhabdosynochus sp. 4 (gills) [0]

Mono: Ancy: Haliotrema sp. (gills) [0]

Tryp: Laci: Pseudogilquinia pillersi (Southwell, 1929) larvae (body cavity) [1]

Tryp: Pseu: Pseudotobothrium dipsacum larvae (body cavity) [0] (NGR)

Nema: Anis: unidentified larvae (digestive tract) [0]

Nema: Phil: Philometra ocularis Moravec, Ogawa, Suzuki, Miyazaki et Donai, 2002 (orbits) [22]

Remarks: Based on examination of 1 specimen ( 1 for gills, 1 for abdominal organs)

Host-parasite combinations: 11; with species-level identification: 4.

Epinephelus cyanopodus (Richardson, 1846)

Isop: Gnat: Praniza larvae (gills) [27]

Isop: Cora: Argathona rhinoceros (gills) [27] (NHR)

Cope: Cali: Caligus asymmetricus Kabata, 1965 (gills) [0] (NHR)

Cope: Cali: Lepeophtheirus plectropomi Nunes-Ruivo et Fourmanoir, 1956 (gills) [0] (NHR)

Cope: Hats: Hatschekia n. sp. 1 (gills) [0]

Cope: Hats: Hatschekia n. sp. 11 (gills) [0]

Cope: Diss: Dissonus manteri Kabata, 1966 (gills) [2][27]

Cope: Lern: Sagum epinepheli (gills) [27] (NHR)

Cope: Penn: larvae (gills) [27]

Mono: Ancy: Haliotrema sp. (gills) [27]

Mono: Caps: Allobenedenia sp. (gills) [27]

Mono: Dipl: Pseudorhabdosynochus cyanopodus Sigura et Justine, 2008 (gills) [27]

Mono: Dipl: Pseudorhabdosynochus podocyanus Sigura et Justine, 2008 (gills) [27]

Mono: Dipl: Pseudorhabdosynochus chauveti Sigura et Justine, 2008 (gills) [27]

Mono: Dipl: Pseudorhabdosynochus exoticus Sigura et Justine, 2008 (gills) [27]

Mono: Dipl: Pseudorhabdosynochus duitoe Justine, 2007 (gills) [27]

Mono: Dipl: Pseudorhabdosynochus huitoe Justine, 2007 (gills) [27]

Mono: Dipl: Laticola cyanus Sigura et Justine, 2008 (gills) [27]

Dige: Buce: Prosorhynchus longisaccatus (digestive tract) [3]

Dige: Didy: unidentified adults (gills) [27]

Dige: Didy: unidentified adults (fins) [27]

Dige: Fell: Tergestia sp. immature (digestive tract) [27]

Dige: Hemi: Erilepturus hamati (Yamaguti, 1934) (digestive tract) [27]

Dige: Opec: Allopodocotyle epinepheli (Yamaguti, 1942) (digestive tract) [5]

Dige: Opec: Cainocreadium epinepheli (digestive tract) [27]

Tetr: Unid: larvae (digestive tract) [0]

Tryp: Laci: Pseudolacistorhynchus heroniensis larvae (body cavity) [27]

Tryp: Laci: Floriceps minacanthus larvae (body cavity) [27]

Nema: Phil: Philometra ocularis (orbits) [22]

Nema: Phil: Philometra cyanopodi Moravec et Justine, 2008 (ovaries) [23]

Nema: Anis: Terranova sp. larvae (digestive tract) [27]

Remarks: Based on examination of 25 specimens (21 for gills, 14 for abdominal organs).

Host-parasite combinations: 31; with species-level identification: 20

The hemiurid Erilepturus tiegsi Woolcock, 1935 was recorded from

"loche bleue" off New Caledonia (Manter 1969), which most prob- 
ably corresponds to this host (Justine 2007a). Our findings did not confirm this record.

An exhaustive comparison of the parasitic fauna of this species in various locations was performed (Sigura and Justine 2008).

\section{Epinephelus fasciatus (Forsskål, 1775)}

Cope: Cali: Caligus n. sp. (gills) [0]

Cope: Hats: Hatschekia n. sp. 1 (gills) [0]

Mono: Caps: Benedenia cf. epinepheli (gills) [0]

Mono: Dipl: Pseudorhabdosynochus caledonicus Justine, 2005 (gills) [9]

Mono: Dipl: Pseudorhabdosynochus youngi Justine, Dupoux et Cribb, 2009 (gills) [17]

Dige: Bive: Bivesicula sp. (digestive tract) [0]

Dige: Didy: unidentified adults (opercula) [0]

Dige: Didy: unidentified larvae (digestive tract) [0]

Dige: Gorg: Phyllodistomum sp. (digestive tract) [0]

Dige: Hemi: Lecithochirium sp. (digestive tract) [0]

Dige: Lepo: Lepidapedoides angustus Bray, Cribb et Barker, 1996 (digestive tract) [3]

Dige: Opec: Allopodocotyle epinepheli (digestive tract) [5]

Dige: Opec: Cainocreadium epinepheli (digestive tract) [5]

Dige: Opec: Helicometra epinepheli (Yamaguti, 1934) (digestive tract) [5]

Tetr: Unid: larvae (digestive tract) [0]

Tryp: Laci: Pseudolacistorhynchus heroniensis larvae (body cavity) [0] (NHR)

Tryp: Pseu: Pseudotobothrium dipsacum larvae (body cavity) [0] (NHR)

Nema: Anis: unidentified larvae (digestive tract) [0]

Nema: Cama: Procamallanus variolae Moravec, Justine et Rigby, 2006 (digestive tract) [25]

Nema: Phil: Philometra fasciati Moravec et Justine, 2008 (ovaries) [23][25]

Turbellaria: Unid: unidentified species (skin) [19]

Remarks: Based on examination of 92 specimens ( 45 for gills, 61 for abdominal organs).

Host-parasite combinations: 21; with species-level identification: 10.

Epinephelus fuscoguttatus (Forsskål, 1775)

Isop: Gnat: Praniza larvae (gills) [0]

Cope: Cali: Lepeophtheirus sp. (gills) [0]

Cope: Hats: Hatschekia n. sp. 5 (gills) [0]

Cope: Siph: larvae (gills) [0]

Mono: Caps: Trochopodinae sp. 4 of Perkins et al. (2009) (gills) [0]

Mono: Dipl: Pseudorhabdosynochus sp. 1 (gills) [0]

Mono: Dipl: Pseudorhabdosynochus sp. 2 (gills) [0]

Nema: Anis: unidentified larvae (digestive tract) [0]

Remarks: Based on examination of 2 specimens ( 2 for gills, 1 for abdominal organs).

Host-parasite combinations: 8; with species-level identification: 0 .

Epinephelus howlandi (Günther, 1873)

Isop: Cymo: Elthusa sp. (gills) [0]

Mono: Dipl: Pseudorhabdosynochus venus Hinsinger et Justine, 2006 (gills) [6]

Mono: Dipl: Pseudorhabdosynochus cyathus Hinsinger et Justine, 2006 (gills) [7]

Tryp: Laci: Pseudolacistorhynchus heroniensis larvae (body cavity) [0] (NHR)

Nema: Anis: unidentified larvae (digestive tract) [0]

Remarks: Based on examination of 24 specimens ( 23 for gills, 3 for abdominal organs).

Host-parasite combinations: 5; with species-level identification: 3 .

Epinephelus maculatus (Bloch, 1790)

Isop: Gnat: Praniza larvae (gills) [0]

Cope: Cali: Lepeophtheirus epinepheli (gills) [0] (NHR)

Cope: Diss: Dissonus manteri (gills) [2]

Cope: Hats: Hatschekia n. sp. 1 (gills) [0]
Cope: Hats: Hatschekia n. sp. 10 (gills) [0]

Cope: Penn: larvae (gills) [0]

Mono: Ancy: Haliotrema cf. epinepheli (gills) [11]

Mono: Ancy: Haliotrema sp. of Justine, 2007 (gills) [11]

Mono: Caps: unidentified (gills) [0]

Mono: Dipl: Diplectanum uitoe Justine, 2007

Mono: Dipl: Laticola dae Journo et Justine, 2006 (gills) [8]

Mono: Dipl: Pseudorhabdosynochus auitoe Justine, 2007 (gills) [11]

Mono: Dipl: Pseudorhabdosynochus buitoe Justine, 2007 (gills) [11]

Mono: Dipl: Pseudorhabdosynochus cuitoe Justine, 2007 (gills) [11]

Mono: Dipl: Pseudorhabdosynochus duitoe Justine, 2007 (gills) [11]

Mono: Dipl: Pseudorhabdosynochus euitoe Justine, 2007 (gills) [11]

Mono: Dipl: Pseudorhabdosynochus fuitoe Justine, 2007 (gills) [11]

Mono: Dipl: Pseudorhabdosynochus guitoe Justine, 2007 (gills) [11]

Mono: Dipl: Pseudorhabdosynochus huitoe Justine, 2007 (gills) [11]

Dige: Acan: Stephanostomum japonocasum (digestive tract) [0] (NHR*)

Dige: Buce: Prosorhynchus longisaccatus (digestive tract) [0] (NHR*)

Dige: Didy: unidentified adults (gills, orbit, branchiostegal membranes) [0]

Dige: Didy: unidentified larvae (digestive tract, swim bladder) [0]

Dige: Hemi: Erilepturus hamati (digestive tract) [0]

Dige: Hemi: Lecithochirium sp. 1 (digestive tract) [0]

Dige: Hemi: Lecithochirium sp. 2 (digestive tract) [0]

Dige: Hemi: Aphanurus sp. (digestive tract) [0]

Dige: Hemi: Tubulovesicula angusticauda (Nicoll, 1915) (digestive tract) [0] (NHR) (NGR)

Dige: Lepo: Lepidapedoides angustus (gall bladder) [0] (NHR)

Dige: Opec: Cainocreadium epinepheli (digestive tract) [0] (NHR)

Dige: Opec: Helicometra epinepheli (digestive tract) [0] (NHR)

Both: Unid: larvae (flesh) [0]

Tetr: Unid: larvae (digestive tract) $[0]$

Tryp: Otob: Otobothrium sp. larvae (body cavity) [0]

Nema: Cama: unidentified species (digestive tract) [0]

Nema: Anis: unidentified larvae (digestive tract) [0]

Remarks: Based on examination of 62 specimens ( 38 for gills, 38 for abdominal organs)

Host-parasite combinations: 36; with species-level identification: 19

Epinephelus malabaricus (Bloch et Schneider, 1801)

Isop: Cora: Argathona rhinoceros (gills) [0]

Cope: Hats: Hatschekia n. sp. 6 (gills) [0]

Cope: Cali: Lepeophtheirus plectropomi (gills) [0] (NHR)

Cope: Siph: chalimus larvae (gills) [0]

Mono: Ancy: Haliotrema sp. 1 (gills) [20]

Mono: Ancy: Haliotrema sp. 2 (gills) [20]

Mono: Caps: Allobenedenia sp. (gills) [0]

Mono: Dipl: Diplectanum maa Justine et Sigura, 2007 (gills) [20]

Mono: Dipl: Pseudorhabdosynochus $\mathrm{cf}$. shenzhenensis (gills) [20]

Mono: Dipl: Pseudorhabdosynochus maaensis Justine et Sigura, 2007 (gills) [20]

Mono: Dipl: Pseudorhabdosynochus malabaricus Justine et Sigura, 2007 (gills) [20]

Mono: Dipl: Pseudorhabdosynochus manifestus Justine et Sigura, 2007 (gills) [20]

Mono: Dipl: Pseudorhabdosynochus manipulus Justine et Sigura, 2007 (gills) [20]

Mono: Dipl: Pseudorhabdosynochus marcellus Justine et Sigura, 2007 (gills) [20]

Mono: Dipl: Pseudorhabdosynochus maternus Justine et Sigura, 2007 (gills) [20]

Dige: Buce: Prosorhynchus maternus Bray et Justine, 2006 (digestive tract) [3]

Dige: Opec: Cainocreadium sp. (digestive tract) [0]

Tryp: Laci: Pseudogilquinia pillersi larvae (body cavity) [1]

Tryp: Pseu: Pseudotobothrium dipsacum larvae (body cavity) [20]

Nema: Unid: (digestive tract)

Remarks: Based on examination of 2 specimens ( 2 for gills, 2 for abdominal organs).

Host-parasite combinations: 20; with species-level identification: 12 .

An exhaustive comparison of the parasitic fauna of this species in various locations was performed (Justine and Sigura 2007). 


\section{Epinephelus merra Bloch, 1793}

Cope: Cali: Lepeophtheirus sp. (gills) [0]

Cope: Lern: Sagum epinepheli (gills) [0] (NHR)

Cope: Penn: larvae (gills) [0]

Cope: Siph: larvae (gills) [0]

Mono: Dipl: Pseudorhabdosynochus melanesiensis Laird, 1958 (gills) [9]

Mono: Dipl: Pseudorhabdosynochus cf. coioidesis (gills) [7]

Mono: Caps: unidentified Benedeniinae (gills) [0]

Dige: Opec: Helicometra epinepheli Yamaguti, 1934 (digestive tract) [5]

Dige: Opec: Allopodocotyle epinepheli (Yamaguti, 1942) (digestive tract) [5]

Remarks: Based on examination of 64 specimens ( 58 for gills, 18 for abdominal organs)

Host-parasite combinations: 9; with species-level identification: 4. Additional records: The digeneans Helicometra fasciata (Opecoelidae) and Lepidapedoides angustus (Lepocreadiidae; as L. 'kerapu', see note on species name in Justine 2007a), the unidentified cestode 'Scolex polymorphus' and unidentified trypanorhynch larvae were recorded off New Caledonia (Rigby et al. 1997). Curiously, our findings did not confirm any of these records, although ' $S$. polymorphus' probably indicated the presence of tetraphyllidean cestode larvae.

Epinephelus morrhua (Valenciennes, 1833)

Isop: Gnat: Praniza larvae (gills) [0]

Cope: Hats: Hatschekia cernae Goggio, 1905 (gills) [0] (NHR)

Cope: Hats: Hatschekia n. sp. 4 (gills) [0]

Cope: Lern: Sagum epinepheli (gills) [0] (NHR)

Mono: Ancy: Haliotrema sp. of Justine 2008b (gills) [14]

Mono: Dipl: Pseudorhabdosynochus morrhua Justine, 2008 (gills) [14]

Mono: Dipl: Pseudorhabdosynochus variabilis Justine, 2008 (gills) [14]

Dige: Bive: Bivesicula sp. (digestive tract) [0]

Dige: Buce: Prosorhynchus sp. (digestive tract) [0]

Dige: Didy: unidentified larvae (gills)

Dige: Opec: Cainocreadium epinepheli (digestive tract) [0]

Tetr: unidentified larvae (digestive tract) [0]

Tryp: unidentified larvae (body cavity) [0]

Nema: Anis: unidentified larvae (digestive tract) [0]

Acantho: unidentified acanthocephalan species (digestive tract) [0]

Remarks: Based on examination of 5 specimens ( 5 for gills, 4 for abdominal organs)

Host-parasite combinations: 15; with species-level identification: 5.

Epinephelus polyphekadion (Bleeker, 1849)

Isop: Gnat: Praniza larvae (gills) [0]

Cope: Hats: Hatschekia n. sp. 1 (gills) [0]

Mono: Caps: Benedenia cf. epinepheli (gills) [0]

Mono: Dipl: Pseudorhabdosynochus sp. 1 (gills) [0]

Mono: Dipl: Pseudorhabdosynochus sp. 2 (gills) [0]

Mono: Dipl: Pseudorhabdosynochus sp. 3 (gills) [0]

Dige: Didy: unidentified adults (muscles) [0]

Dige: Hemi: Lecithochirium sp. (digestive tract) [0]

Both: Unid: larvae (flesh) [0]

Tryp: Laci: Pseudolacistorhynchus heroniensis larvae (body cavity) [0] (NHR)

Remarks: Based on examination of 8 specimens ( 6 for gills, 3 for abdominal organs).

Host-parasite combinations: 10; with species-level identification: 1.

\section{Epinephelus retouti (Bleeker, 1868)}

Mono: Dipl: Pseudorhabdosynochus cupatus-group n. sp.

Dige: Acan: Stephanostomum japonocasum (digestive tract) [0]

Dige: Didy: unidentified larvae (digestive tract) [0]

Dige: Hemi: Lecithochirium sp. (digestive tract) [0]

Tryp: Pseu: Pseudotobothrium dipsacum larvae (body cavity) [0] (NHR)
Nema: Anis: unidentified larvae (digestive tract) [0]

Nema: Cama: unidentified (digestive tract) [0]

Remarks: Based on examination of 2 specimens ( 1 for gills, 2 for abdominal organs)

Host-parasite combinations: 7; with species-level identification: 2.

Epinephelus rivulatus (Valenciennes, 1830)

Isop: Gnat: Praniza larvae (gills) [0]

Cope: Hats: Hatschekia n. sp. 1 (gills) [0]

Mono: Caps: unidentified immature (gills) [0]

Mono: Dipl: Pseudorhabdosynochus calathus Hinsinger et Justine, 2006 (gills) [7]

Mono: Dipl: Pseudorhabdosynochus inversus Justine, 2008 (gills) [15]

Dige: Didy: unidentified larvae (digestive tract) [0]

Dige: Hemi: Lecithochirium sp (digestive tract) [0]

Tetr: Unid: larvae (digestive tract) [0]

Tryp: Laci: Pseudolacistorhynchus heroniensis larvae (body cavity) [0] (NHR)

Tryp: Laci: Callitetrarhynchus gracilis larvae (body cavity) [0] (NHR)

Nema: Phil: Philometra ocularis (orbit) [22]

Remarks: Based on examination of 14 specimens ( 14 for gills, 8 for abdominal organs).

Host-parasite combinations: 11; with species-level identification: 5.

Plectropomus laevis (Lacépède, 1801)

Isop: Cora: Argathona macronema (Bleeker, 1857) (gills) [0] (NHR)

Cope: Diss: Dissonus manteri (gills) [2]

Cope: Hats: Hatschekia plectropomi Ho et Dojiri, 1978 (gills) [0] (NHR)

Cope: Penn: larvae (gills) [0]

Mono: Dipl: Echinoplectanum chauvetorum Justine et Euzet, 2006 (gills) [18]

Mono: Dipl: Echinoplectanum laeve Justine et Euzet, 2006 (gills) [18]

Dige: Buce: Prosorhynchus sp. (digestive tract) [0]

Dige: Buce: Neidhartia sp. 2 (digestive tract) [0]

Dige: Opec: unidentified immature (digestive tract) [0]

Both: Unid: larvae (digestive tract) [0]

Tryp: Laci: Floriceps minacanthus larvae (body cavity) [0] (NHR)

Tryp: Laci: Pseudogilquinia pillersi larvae (body cavity) [1]

Tryp: Pseu: Pseudotobothrium dipsacum larvae (body cavity) [0] (NHR)

Nema: Capi: unidentified species (digestive tract) [0]

Nema: Anis: Hysterothylacium sp. larvae (digestive tract) [0]

Remarks: Based on examination of 14 specimens ( 14 for gills, 6 for abdominal organs)

Host-parasite combinations: 15; with species-level identification: 8 .

Plectropomus leopardus (Lacépède, 1802)

Isop: Cora: Argathona macronema (gills) [0]

Isop: Cora: Argathona rhinoceros (gills) [0]

Cope: Cali: Lepeophtheirus sp. (gills) [0]

Cope: Diss: Dissonus manteri (gills) [2]

Cope: Lern: Sagum epinepheli (gills) [0] (NHR)

Cope: Hats: Hatschekia plectropomi (gills) [0]

Cope: Penn: larvae (gills) [0]

Mono: Dipl: Echinoplectanum leopardi Justine et Euzet, 2006 (gills) [18]

Mono: Dipl: Echinoplectanum pudicum Justine et Euzet, 2006 (gills) [18]

Mono: Dipl: Echinoplectanum rarum Justine et Euzet, 2006 (gills) [18]

Mono: Caps: Trochopodinae sp. 2 of Perkins et al. (2009) (gills) [0]

Dige: Buce: Prosorhynchus sp. (digestive tract) [0]

Dige: Buce: Neidhartia sp. 1 (digestive tract) [0]

Dige: Buce: Neidhartia sp. 2 (digestive tract) [0]

Dige: Opec: Pacificreadium serrani (Nagaty et Abdel-Aal, 1962) (digestive tract) $[5]$ 
Tetr: Unid: larvae (digestive tract) [0]

Tryp: Laci: Floriceps minacanthus larvae (body cavity) [0] (NGR)

Tryp: Laci: Pseudogilquinia pillersi larvae (body cavity) [0] (NHR)

Tryp: Pseu: Pseudotobothrium dipsacum larvae (body cavity) [0] (NGR)

Nema: Capi: unidentified adult (digestive tract) [0]

Remarks: Based on examination of 42 specimens ( 21 for gills, 24 for abdominal organs).

Host-parasite combinations: 20; with species-level identification: 12 .

Variola albimarginata Baissac, 1952

Isop: Gnat: Praniza larvae (gills) [0]

Cope: Hats: Hatschekia n. sp. 1 (gills) [0]

Cope: Hats: Hatschekia n. sp. 8 (gills) [0]

Mono: Ancy: Haliotrema cf. epinepheli (gills) [0]

Dige: Buce: Prosorhynchus serrani Durio et Manter, 1968 (digestive tract) [0]

Nema: Anis: Terranova sp. larvae (digestive tract) [0]

Nema: Cama: Procamallanus variolae (digestive tract) [25]

Nema: Cucu: Cucullanus sp. (digestive tract) [0]

Remarks: Based on examination of 4 specimens ( 4 for gills, 2 for

abdominal organs).

Host-parasite combinations: 8; with species-level identification: 2 .

Variola louti (Forsskål, 1775)

Isop: Gnat: Praniza larvae (gills) [0]

Cope: Hats: Hatschekia n. sp. 1 (gills) [0]

\section{Appendix 2: Parasite-host list}

Isopoda

(5 'species'; 3 identified species)

Cora: Argathona macronema (NGR)

Plectropomus laevis (NHR)

Plectropomus leopardus

Cora: Argathona rhinoceros (NGR)

Epinephelus coioides (NHR)

Epinephelus cyanopodus (NHR)

Epinephelus malabaricus

Plectropomus leopardus

Cora: Lanocira zeylanica (NGR)

Cephalopholis boenak (NHR)

Cymo: Elthusa sp.

Epinephelus howlandi

Gnat: Praniza larvae

Cephalopholis argus

Cephalopholis boenak

Cephalopholis urodeta

Epinephelus areolatus

Epinephelus cyanopodus

Epinephelus fuscoguttatus

Epinephelus maculatus

Epinephelus morrhua

Epinephelus polyphekadion

Epinephelus rivulatus

Variola albimarginata

Variola louti

\section{Copepoda}

(19 'species'; 7 identified species)

Cali: Caligus asymmetricus

Epinephelus cyanopodus (NHR)

Cali: Caligus n. sp.

Epinephelus fasciatus

Cali: Lepeophtheirus epinepheli

Epinephelus coeruleopunctatus (NHR)

Epinephelus maculatus (NHR)

Cali: Lepeophtheirus plectropomi

Epinephelus cyanopodus (NHR)

Epinephelus malabaricus (NHR)
Cope: Hats: Hatschekia n. sp. 8 (gills) [0]

Cope: Siph: larvae (gills) [0]

Mono: Dipl: Pseudorhabdosynochus hirundineus Justine, 2005 (gills) [10]

Mono: Ancy: Haliotrema cf. epinepheli (gills) [10]

Dige: Acan: Stephanostomum japonocasum (digestive tract) [0]

Dige: Buce: Prosorhynchus serrani (digestive tract) [3]

Dige: Didy: unidentified adults (body) [0]

Dige: Didy: unidentified larvae (digestive tract) [0]

Dige: Opec: Cainocreadium epinepheli (digestive tract) [5]

Dige: Opec: Pacificreadium serrani (digestive tract) [0]

Tryp: Laci: Callitetrarhynchus gracilis larvae (body cavity) [0] (NHR)

Tryp: Laci: Floriceps minacanthus larvae (body cavity) [0] (NGR)

Tryp: Laci: Diesingium cf. lomentaceum (Diesing, 1850) larvae (body cavity) [0]

Tryp: Pseu: Pseudotobothrium dipsacum larvae (body cavity) [0] (NGR)

Nema: Phil: Philometra ocularis (orbit) [25]

Nema: Cama: Procamallanus sp. (digestive tract) [0]

Nema: Cucu: Cucullanus sp. (digestive tract) [0]

Nema: Anis: Terranova sp. larvae (digestive tract) [0]

Remarks: Based on examination of 34 specimens ( 28 for gills, 18 for abdominal organs).

Host-parasite combinations: 20; with species-level identification: 9. Additional records: Prosorhynchus serrani was described from the same host in New Caledonia (Durio and Manter 1968a); this is confirmed by our findings.
Cali: Lepeophtheirus sp.

Epinephelus fuscoguttatus Epinephelus merra

Plectropomus leopardus

Diss: Dissonus manteri

Epinephelus cyanopodus Epinephelus maculatus

Plectropomus laevis

Plectropomus leopardus

Hats: Hatschekia cernae Epinephelus morrhua (NHR)

Hats: Hatschekia plectropomi

Plectropomus laevis (NHR)

Plectropomus leopardus

\section{Hats: Hatschekia n. sp. 1}

Epinephelus coeruleopunctatus

Epinephelus cyanopodus

Epinephelus fasciatus

Epinephelus maculatus

Epinephelus polyphekadion

Epinephelus rivulatus

Variola albimarginata

Variola louti

Hats: Hatschekia n. sp. 2

Epinephelus chlorostigma

Hats: Hatschekia n. sp. 4

Epinephelus morrhua

Hats: Hatschekia n. sp. 5

Epinephelus fuscoguttatus

Hats: Hatschekia n. sp. 6

Epinephelus malabaricus

Hats: Hatschekia n. sp. 8

Variola albimarginata

Variola louti

Hats: Hatschekia n. sp. 10

Epinephelus maculatus

Hats: Hatschekia n. sp. 11

Epinephelus cyanopodus

Lern: Sagum epinepheli

Epinephelus chlorostigma (NHR)

Epinephelus coeruleopunctatus (NHR)
Epinephelus cyanopodus (NHR)

Epinephelus merra (NHR)

Epinephelus morrhua (NHR)

Plectropomus leopardus (NHR)

Penn: Larvae

Cephalopholis sonnerati

Cephalopholis urodeta

Epinephelus cyanopodus

Epinephelus maculatus

Epinephelus merra

Plectropomus laevis

Plectropomus leopardus

Siph: Larvae

Anyperodon leucogrammicus

Cephalopholis spiloparaea

Cromileptes altivelis

Epinephelus fuscoguttatus

Epinephelus malabaricus

Epinephelus merra

Variola louti

Monogenea

(56 'species'; 42 identified species)

Ancy: Haliotrema cf. cromileptis Cromileptes altivelis

Ancy: Haliotrema cf. epinepheli

Epinephelus maculatus

Variola albimarginata

Variola louti

Ancy: Haliotrema spp.

Cephalopholis sonnerati

Epinephelus chlorostigma

Epinephelus coeruleopunctatus

Epinephelus coioides

Epinephelus cyanopodus

Epinephelus maculatus

Epinephelus malabaricus

Epinephelus morrhua

Caps: Allobenedenia cf. epinepheli

Epinephelus chlorostigma

Epinephelus coioides

Caps: Allobenedenia spp.

Epinephelus cyanopodus

Epinephelus malabaricus 
Caps: Benedenia cf. epinepheli

Epinephelus fasciatus

Epinephelus polyphekadion

Caps: Unidentified Benedeniinae spp.

Cephalopholis miniata

Cephalopholis sonnerati

Epinephelus merra

Caps: Trochopodinae sp. 2 of Perkins et al. 2009

Plectropomus leopardus

Caps: Trochopodinae sp. 4 of Perkins et al. 2009

Epinephelus fuscoguttatus

Caps: Unidentified spp.

Cephalopholis argus

Cephalopholis urodeta

Epinephelus areolatus

Epinephelus maculatus

Epinephelus rivulatus

Dipl: Diplectanum maa

Epinephelus malabaricus

Dipl: Diplectanum nanus

Cephalopholis sonnerati

Dipl: Diplectanum parvus

Cephalopholis urodeta

Dipl: Diplectanum uitoe

Epinephelus maculatus

Dipl: Diplectanum spp.

Cephalopholis miniata

Epinephelus areolatus

Dipl: Echinoplectanum chauvetorum

Plectropomus laevis

Dipl: Echinoplectanum laeve

Plectropomus laevis

Dipl: Echinoplectanum leopardi

Plectropomus leopardus

Dipl: Echinoplectanum pudicum

Plectropomus leopardus

Dipl: Echinoplectanum rarum

Plectropomus leopardus

Dipl: Laticola cyanus

Epinephelus cyanopodus

Dipl: Laticola dae

Epinephelus maculatus

Dipl: Pseudorhabdosynochus argus

Cephalopholis argus

Dipl: Pseudorhabdosynochus auitoe

Epinephelus maculatus

Dipl: Pseudorhabdosynochus bacchus

Epinephelus coeruleopunctatus

Dipl: Pseudorhabdosynochus buitoe

Epinephelus maculatus

Dipl: Pseudorhabdosynochus calathus Epinephelus rivulatus

Dipl: Pseudorhabdosynochus caledonicus Epinephelus fasciatus

Dipl: Pseudorhabdosynochus chauveti Epinephelus cyanopodus

Dipl: Pseudorhabdosynochus cuitoe Epinephelus maculatus

Dipl: Pseudorhabdosynochus cyanopodus Epinephelus cyanopodus

Dipl: Pseudorhabdosynochus cyathus Epinephelus howlandi

Dipl: Pseudorhabdosynochus duitoe

Epinephelus cyanopodus

Epinephelus maculatus
Dipl: Pseudorhabdosynochus epinepheli Epinephelus chlorostigma

Dipl: Pseudorhabdosynochus exoticus Epinephelus cyanopodus

Dipl: Pseudorhabdosynochus fuitoe Epinephelus maculatus

Dipl: Pseudorhabdosynochus guitoe Epinephelus maculatus

Dipl: Pseudorhabdosynochus hirundineus Variola louti

Dipl: Pseudorhabdosynochus huitoe

Epinephelus cyanopodus

Epinephelus maculatus

Dipl: Pseudorhabdosynochus inversus Epinephelus rivulatus

Dipl: Pseudorhabdosynochus maaensis Epinephelus malabaricus

Dipl: Pseudorhabdosynochus malabaricus Epinephelus malabaricus

Dipl: Pseudorhabdosynochus manifestus Epinephelus malabaricus

Dipl: Pseudorhabdosynochus manipulus Epinephelus malabaricus

Dipl: Pseudorhabdosynochus marcellus Epinephelus malabaricus

Dipl: Pseudorhabdosynochus maternus Epinephelus malabaricus

Dipl: Pseudorhabdosynochus melanesien-

Epinephelus merra

Dipl: Pseudorhabdosynochus minutus Cephalopholis sonnerati

Dipl: Pseudorhabdosynochus morrhua Epinephelus morrhua

Dipl: Pseudorhabdosynochus podocyanus Epinephelus cyanopodus

Dipl: Pseudorhabdosynochus variabilis Epinephelus morrhua

Dipl: Pseudorhabdosynochus venus Epinephelus howland

Dipl: Pseudorhabdosynochus young Epinephelus fasciatus

Dipl: Pseudorhabdosynochus cf. coioidesis Epinephelus merra

Dipl: Pseudorhabdosynochus cf. shenzhenensis

Epinephelus malabaricus

Dipl: Pseudorhabdosynochus spp.

Anyperodon leucogrammicus

Epinephelus areolatus

Epinephelus chlorostigma

Epinephelus coeruleopunctatus

Epinephelus coioides

Epinephelus fuscoguttatus

Epinephelus polyphekadion

Epinephelus retouti

Digenea

(28 'species'; 13 identified species)

Acan: Stephanostomum japonocasum

Cephalopholis urodeta

Epinephelus areolatus

Epinephelus chlorostigma

Epinephelus maculatus (NHR*)

Epinephelus retouti

Variola louti

Bive: Bivesicula claviformis

Cephalopholis boenak
Bive: Bivesicula sp.

Epinephelus chlorostigma

Epinephelus fasciatus

Epinephelus morrhua

Buce: Neidhartia sp. 1

Plectropomus leopardus

Buce: Neidhartia sp. 2

Plectropomus laevis

Plectropomus leopardus

Buce: Prosorhynchus longisaccatus

Epinephelus areolatus (NHR*)

Epinephelus cyanopodus

Epinephelus maculatus (NHR*)

Buce: Prosorhynchus maternus

Epinephelus malabaricus

Buce: Prosorhynchus robertsthomsoni Cephalopholis argus

Buce: Prosorhynchus serrani

Variola albimarginata

Variola louti

Buce: Prosorhynchus sp.

Cephalopholis urodeta

Epinephelus chlorostigma

Epinephelus coeruleopunctatus

Epinephelus morrhua

Plectropomus laevis

Plectropomus leopardus

Dero: Derogenes-like sp.

Epinephelus coeruleopunctatus

Didy: Unidentified adult

Cephalopholis miniata

Epinephelus chlorostigma

Epinephelus cyanopodus

Epinephelus fasciatus

Epinephelus maculatus

Epinephelus polyphekadion

Variola louti

Didy: Unidentified larvae

Epinephelus fasciatus

Epinephelus maculatus

Epinephelus morrhua

Epinephelus retouti

Epinephelus rivulatus

Variola louti

Fell: Tergestia sp.

Epinephelus cyanopodus

Gorg: Phyllodistomum sp.

Epinephelus fasciatus

Hemi: Erilepturus hamati

Epinephelus cyanopodus

Epinephelus maculatus

Hemi: Lecithochirium sp.

Epinephelus chlorostigma

Epinephelus fasciatus

Epinephelus maculatus

Epinephelus polyphekadion

Epinephelus retouti

Epinephelus rivulatus

Hemi: Aphanurus sp.

Epinephelus maculatus

Hemi: Tubulovesicula angusticauda Epinephelus maculatus

Hemi: Unidentified species

Epinephelus morrhua

Lepo: Lepidapedoides angustus

Epinephelus fasciatus

Epinephelus maculatus

Opec: Allopodocotyle epinepheli

Epinephelus cyanopodus

Epinephelus fasciatus

Epinephelus merra 
Justine et al.: Parasite biodiversity in groupers

Opec: Allopodocotyle sp.

Epinephelus areolatus

Opec: Cainocreadium epinepheli

Cephalopholis miniata

Cephalopholis urodeta

Epinephelus coeruleopunctatus

Epinephelus cyanopodus

Epinephelus fasciatus

Epinephelus maculatus

Epinephelus morrhua

Variola louti

Opec: Helicometra epinepheli

Epinephelus fasciatus

Epinephelus maculatus

Epinephelus merra

Opec: Helicometra sp.

Cephalopholis urodeta

Opec: Pacificreadium serrani

Plectropomus leopardus

Variola louti

Opec: Unidentified species

Epinephelus malabaricus

Plectropomus laevis

\section{Cestoda Bothriocephalidea}

(3 'species'; 1 identified species)

Both: Bothriocephalus celineae

Cephalopholis hybrid: aurantia $\times$ spiloparaea

Unid: Larvae (muscles, flesh)

Epinephelus polyphekadion

Epinephelus maculatus

Unid: Larvae (digestive tract)

Plectropomus laevis

Cestoda Tetraphyllidea

(1 'species'; 0 identified species)

Unid: Larvae (digestive tract)

Cephalopholis boenak

Cephalopholis miniata

Cephalopholis sonnerati

Cephalopholis spiloparaea

Cephalopholis urodeta

Epinephelus chlorostigma

Epinephelus areolatus

Epinephelus cyanopodus

Epinephelus fasciatus

Epinephelus maculatus

Epinephelus morrhua

Epinephelus rivulatus

Plectropomus laevis

\section{Cestoda Trypanorhyncha}

(8 'species'; 5 identified species)

Laci: Callitetrarhynchus gracilis (NGR)

Cephalopholis boenak (NHR)

Epinephelus chlorostigma (NHR)

Epinephelus rivulatus (NHR)

Variola louti (NHR)

Laci: Diesingium cf. lomentaceum

Variola louti

Laci: Floriceps minacanthus (NGR)

Cephalopholis miniata (NHR)

Cephalopholis urodeta (NHR)

Epinephelus cyanopodus

Plectropomus laevis (NHR)

Plectropomus leopardus (NGR)

Variola louti (NGR)

Laci: Pseudogilquinia pillersi

Epinephelus coioides

Epinephelus malabaricus

Plectropomus laevis

Plectropomus leopardus (NHR)
Laci: Pseudolacistorhynchus heroniensis

Cephalopholis boenak (NHR)

Epinephelus chlorostigma (NHR)

Epinephelus cyanopodus

Epinephelus fasciatus (NHR)

Epinephelus howlandi (NHR)

Epinephelus polyphekadion (NHR)

Epinephelus rivulatus (NHR)

Otob: Otobothrium sp.

Epinephelus maculatus

Pseu: Pseudotobothrium dipsacum (NGR)

Cephalopholis miniata (NHR)

Cephalopholis sonnerati (NGR)

Cephalopholis urodeta (NHR)

Epinephelus coioides (NGR)

Epinephelus fasciatus (NHR)

Epinephelus malabaricus (NGR)

Epinephelus retouti (NHR)

Plectropomus laevis (NHR)

Plectropomus leopardus (NGR)

Variola louti (NGR)

Unid: Larvae

Cephalopholis spiloparaea

Epinephelus morrhua

Nematoda

(12 'species'; 4 identified species)

Anis: Anisakis sp. larvae

Epinephelus areolatus

Anis: Hysterothylacium sp.

Plectropomus laevis

Anis: Terranova sp. larvae

Epinephelus areolatus

Epinephelus cyanopodus

Variola albimarginata

Variola louti

Anis: Unidentified larvae

Cephalopholis argus

Cephalopholis boenak

Cephalopholis miniato

Cephalopholis sonnerati

Cephalopholis urodeta

Cromileptes altivelis

Epinephelus chlorostigma

Epinephelus coioides

Epinephelus fasciatus

Epinephelus fuscoguttatus

Epinephelus howlandi

Epinephelus maculatus

Epinephelus morrhua

Epinephelus retouti

Cama: Procamallanus variolae

Epinephelus fasciatus

Variola albimarginata

Cama: Unidentified species

Epinephelus maculatus

Epinephelus retouti

Variola louti

Capi: Unidentified species

Plectropomus laevis

Plectropomus leopardus

Cucu: Cucullanus sp.

Variola albimarginata

Variola louti

Phil: Philometra cyanopodi

Epinephelus cyanopodus

Phil: Philometra fasciati

Epinephelus fasciatus

Phil: Philometra ocularis

Epinephelus areolatus

Epinephelus cyanopodus

Epinephelus rivulatus

Variola lout
Unid: (digestive tract)

Epinephelus malabaricus

Turbellaria

(1 'species'; 0 identified species)

Unid: Unidentified species

Epinephelus fasciatus

Acanthocephala

(1 'species'; 0 identified species)

Unid: Unidentified species

Epinephelus morrhua

\section{Appendix 3: Material deposited}

*: type material

Isopoda

Cora: Argathona rhinoceros ex Pl. leopardus, MNHN Is6246; ex Ep. malabaricus, MNHN Is 6247; ex Ep. coioides, MNHN Is6249; ex Ep. cyanopodus, MNHN Is6252. Cora: Argathona macronema ex Pl. leopardus, MNHN Is6248; ex Pl. laevis, MNHN Is6250, 6251.

Cora: Lanocira zeylanica ex Ce. boenak, MNHN Is6253, 6255, 6256.

Copepoda

Diss: Dissonus manteri, MNHN Cp2427-

Cp2431; BMNH 2007.349-358.

Monogenea

Ancy: Haliotrema epinepheli ex Ep. maculatus, MNHN JNC1131, 1170.

Ancy: Haliotrema spp. ex Ce. sonnerati,

MNHN JNC 1614-5, 1636; ex Ep. macu-

latus, MNHN JNC1101, 1150, 1170, 1190,

1522, 1547.

Caps: Trochopodinae sp. 2 of Perkins et

al. (2009) ex Pl. leopardus, MNHN JNC $1391 \mathrm{~B} 1$.

Caps: Trochopodinae sp. 4 of Perkins et al

(2009) ex Ep. fuscoguttatus, MNHN JNC 1379B2.

Dipl: Diplectanum maa ex Ep. malabaricus, MNHN JNC2130*; BMNH 2007.6.1.6*; USNPC 99871*; HCIP M-441*.

Dipl: Diplectanum nanus ex Ce. sonnerati, MNHN JNC1615*

Dipl: Diplectanum parvus ex Ce. urodeta, MNHN JNC1212*, 1856*; USNPC 100490*; BMNH 2008.1.4.1*; SAMA AHC 29463*.

Dipl: Diplectanum uitoe ex Ep. maculatus, MNHN JNC1061*,1131*,1150*, 1190* 1547*; BMNH 2006.4.4.18*; USNPC 97725*; ZRC PAR.10*

Dipl: Echinoplectanum chauvetorum ex $P l$. laevis, MNHN JNC963*, 1037*; BMNH 2005.7.20.6*; USNPC 97112*

Dipl: Echinoplectanum laeve ex $P$ laevis, MNHN JNC963*, 1037*; BMNH 2005.7.20.7*; USNPC 97111*.

Dipl: Echinoplectanum leopardi ex Pl. leopardus, MNHN JNC 1012*, 1191*, 1392-4*; BMNH 2005.7.20.4*; USNPC 97113*. Dipl: Echinoplectanum pudicum ex $P l$. leopardus, MNHN JNC1012*, 1392-4*; BMNH 2005.7.20.5*; USNPC 97114*. Dipl: Echinoplectanum rarum ex Pl. leopardus, MNHN JNC1392-94*.

Dipl: Laticola cyanus ex Ep. cyanopodus, MNHN JNC1546*, 1625-6*; BMNH 2007.11.23.12-14*; USNPC 100406-7*; SAMA AHC 29303-5*; HCIP M-461*; SLZU 2007112105-1-3*.

Dipl: Laticola dae ex Ep. maculatus, MNHN JNC1061*, 1150*, 1170*; BMNH 
2004.9.15.10-11*; USNPC 95080*; SLZU 2005080807-8*; HCIP M-449.

Dipl: Pseudorhabdosynochus argus ex Ce. $\operatorname{argus,}$ MNHN JNC1425*, 1828*; BMNH 2007.3.1.1*; USNPC 99680*; QM G227642*

Dipl: Pseudorhabdosynochus auitoe ex Ep. maculatus, MNHN JNC1061*, 1101* $1131 *, 1150 *, 1190 *, 1522 *, 1524 *, 1547 *$ BMNH 2006.4.4.1-2*; USNPC 97707-8*; HCIP M-442.

Dipl: Pseudorhabdosynochus bacchus ex Ep. coeruleopunctatus, MNHN JNC1905*; BMNH 2006.12.13.1*; USNPC 99435*; HCIP M-429*.

Dipl: Pseudorhabdosynochus buitoe ex Ep. maculatus, MNHN JNC1101*, 1131*, 1150*, 1170*, 1190*, 1522-4*, 1547*; BMNH 2006.4.4.3-4*; USNPC 97709-10*; HCIP M-443.

Dipl: Pseudorhabdosynochus calathus ex Ep. rivulatus, MNHN JNC1203*, 1283*, $1351 *, 1368 * ;$ BMNH 2005.7.20.3*; USNPC 97000; SLZU 2005080805*

Dipl: Pseudorhabdosynochus caledonicus ex Ep. fasciatus, MNHN JNC1018*, 1082* 1093*, 1094*; USNPC 095078*; BMNH 2004.8.11.3*

Dipl: Pseudorhabdosynochus chauveti ex Ep. cyanopodus, MNHN JNC1625-6*, 1660-1*; BMNH 2007.11.23.5-7*; USNPC 100402-3*; SAMA AHC 29297-8*; HCIP M-459*; SLZU 2007112103-1-2*.

Dipl: Pseudorhabdosynochus cuitoe ex Ep. maculatus, MNHN JNC1061*, 1101*, $1131 *, 1150 *, 1170 *, 1190 *, 1522-4 *$, 1547*; BMNH 2006.4.4.5-6*; USNPC 97711-2*; HCIP M-444.

Pseudorhabdosynochus cyanopodus ex Ep. cyanopodus, MNHN JNC1546*, 1625-6* 1660-1*; BMNH 2007.11.23.1-2*; USNPC 100398-9*; SAMA AHC 29294-5*; HCIP M-457*; SLZU 2007112101-1-2*.

Dipl: Pseudorhabdosynochus cyathus ex Ep. howlandi, MNHN JNC1195*, 1438*; BMNH 2005.7.20.2*; USNPC 96999*; SLZU 2005080804*

Dipl: Pseudorhabdosynochus duitoe ex Ep. maculatus, MNHN JNC1061*, 1101*, $1131 *, 1150 *, 1170 *, 1190 *, 1522-4 *$, 1547*; BMNH 2006.4.4.7-8*; USNPC 97113-4*; HCIP M-445; ex Ep. cyanopodus, MNHN JNC1659, 1902.

Dipl: Pseudorhabdosynochus epinepheli ex Ep. chlorostigma, MNHN JNC2446; BMNH 2008.8-14.2-4; USNPC 101116; MPM 18877; SAMA AHC29538-9; HCIP M-470.

Dipl: Pseudorhabdosynochus euitoe ex Ep. maculatus, MNHN JNC1061*, 1101*, $1131 *, 1150 *, 1170 *, 1190 *, 1522-4 *$, 1547*; BMNH 2006.4.4.9*; USNPC 97715*; HCIP M-446.

Dipl: Pseudorhabdosynochus exoticus ex Ep. cyanopodus, MNHN JNC1546*, 1625-6*, 1660-1*; BMNH 2007.11.23.811*; USNPC 100404-5*; SAMA AHC 29299-300*; HCIP M-460*; SLZU 2007112104-1-4*.

Dipl: Pseudorhabdosynochus fuitoe ex Ep. maculatus, MNHN JNC1101* $1131^{*}, 1150 *, 1170 *, 1190 *, 1522-4 *$, 1547*; BMNH 2006.4.4.10-12*; USNPC 97716-8*; HCIP M-447.
Dipl: Pseudorhabdosynochus guitoe ex Ep. maculatus, MNHN JNC1150*, 1170* 1522-4*; BMNH 2006.4.4.13-14*; USNPC 97719-20*; HCIP M-448.

Dipl: Pseudorhabdosynochus hirundineus ex Va. louti, MNHN JNC994*, 1002*, 1026*; BMNH 2004.8.11.2*; USNPC 95079*

Dipl: Pseudorhabdosynochus huitoe ex Ep. maculatus, MNHN JNC1061*, $1131 *, 1150 *, 1170 *, 1190 *, 1522-4 *$ 1547*; BMNH 2006.4.4.15-17*; USNPC 97723-4*; ex Ep. cyanopodus, MNHN JNC1530, 1901-2.

Dipl: Pseudorhabdosynochus inversus ex Ep. rivulatus, MNHN JNC2606*

Dipl: Pseudorhabdosynochus maaensis ex Ep. malabaricus, MNHN JNC2130*. Dipl: Pseudorhabdosynochus malabaricus ex Ep. malabaricus, MNHN JNC1536*; BMNH 2007.6.1.4*; USNPC 99869*. Dipl: Pseudorhabdosynochus manifestus ex Ep malabaricus, MNHN JNC1536*, 2130*; BMNH 2007.6.1.1-3*; USNPC 99867-8*; SAMA AHC 29213-4*; HCIP M-440*; SLZU 20070613-1-1-3*

Dipl: Pseudorhabdosynochus manipulus ex Ep. malabaricus, MNHN JNC1536*.

Dipl: Pseudorhabdosynochus marcellus ex Ep. malabaricus, MNHN JNC1536*. Dipl: Pseudorhabdosynochus maternus ex Ep. malabaricus, MNHN JNC1536*; BMNH 2007.6.1.5*; USNPC 99870*.

Dipl: Pseudorhabdosynochus melanesiensis ex Ep. merra, MNHN JNC986, 987, 1019 , 1055, 1213, 1223, 1250; USNPC 095082. Dipl: Pseudorhabdosynochus minutus ex Ce. sonnerati, MNHN JNC1614-5*, 1636*; BMNH 2007.3.1.2*; USNPC 99681*

Dipl: Pseudorhabdosynochus morrhua ex Ep. morrhua, MNHN JNC2450*, 2453*, 2462; BMNH 2008.3.17.1*; USNPC 100953*; SAMA AHC 29477*; HCIP M-464*; MPM 18869*

Dipl: Pseudorhabdosynochus podocyanus ex Ep. cyanopodus, MNHN JNC1546*, 1625-6*, 1660*; BMNH 2007.11.23.3-4*; USNPC 100400-1*; SAMA AHC 29296*; HCIP M-458*; SLZU 2007112102-1*.

Dipl: Pseudorhabdosynochus variabilis ex Ep. morrhua, MNHN JNC2450*, 2453*, JNC2462; BMNH 2008.3.17.2*; USNPC 100954*; SAMA AHC29478*; HCIP M-463*; MPM 18870*

Dipl: Pseudorhabdosynochus venus ex Ep. howlandi, MNHN JNC1120*, 1451*, 1478*; BMNH 2005.7.20.1*; USNPC 97110*

Dipl: Pseudorhabdosynochus youngi ex Ep. fasciatus, MNHN JNC985*, 1017*, 10178*, 1035-6*; QM G23161-2*; USNPC 95081*, 101565*; BMNH 2009.2.25.1* Dipl: Pseudorhabdosynochus cf. coioidesis ex Ep. merra, MNHN JNC 1440, 1492 , 1494, 1499.

Dipl: Pseudorhabdosynochus cf. shenzhenensis ex Ep. malabaricus, MNHN JNC2130.

\section{Digenea}

Buce: Prosorhynchus maternus ex Ep. malabaricus, MNHN JNC1536D*; BMNH 2006.4.27.14-16*; HCIP D-596*.
Buce: Prosorhynchus longisaccatus ex Ep. cyanopodus, MNHN JNC1659; BMNH 2006.4.57.1-10.

Lepo: Lepidapedoides angustus ex Ep. fasciatus, MNHN JNC1666, 1667; BMNH 2006.8.23.6

Opec: Allopodocotyle epinepheli ex Ep cyanopodus, MNHN JNC1267; BMNH

2006.11.8.44-45; ex Ep. fasciatus, JNC1667; BMNH 2006.11.8.44-45; ex Ep. merra, MNHN JNC1434; BMNH 2006.11.8.4

Opec: Cainocreadium epinepheli ex Ep. coeruleopunctatus, MNHN JNC1905; ex Ep. fasciatus, MNHN JNC1791, 1792; BMNH 2006.11.8.1-2; ex Va. louti, MNHN JNC1662; BMNH 2006.11.8.17-18. Opec: Helicometra epinepheli ex Ep fasciatus, MNHN JNC1023, 1636B, 1658A, 1664, 1787, BMNH 2006.11.8.19-29; ex Ep. merra, MNHN JNC1433, 1434 $1649,1650,1652,1653,1827 ; \mathrm{BMNH}$ 2006.11.8.30-40.

Opec: Pacificreadium serrani ex Pl. leopardus, MNHN JNC1392E1-E11; BMNH 2006.11.8.3-10

\section{Cestoda Bothriocephalidea}

Both: Bothriocephalus celineae, ex $C e$. aurantia $\times$ spiloparaea, MNHN JNC1926*.

\section{Cestoda Tetraphyllidea} none

\section{Cestoda Trypanorhyncha}

Laci: Pseudogilquinia pillersi ex Ep. coioides, MNHN JNC1535; ex Ep. malabaricus, JNC1536; ex Pl. laevis, JNC1865, 1887. Laci: Pseudolacistorhynchus heroniensis, ex Ep. fasciatus, MNHN JNC1256, 1636, 1758, 1791, 1792; ex Ep. polyphekadion, JNC1915; ex Ep. rivulatus, JNC 1545. Laci: Floriceps minacanthus, ex Ep. cyanopodus, MNHN JNC1998; ex Pl. laevis; ex Va. louti, JNC1859.

Pseu: Pseudotobothrium dipsacum, ex Ce. sonnerati, MNHN JNC1616; ex Ep. coioides, JNC1535; ex Ep. fasciatus, JNC1791; ex Pl. laevis, JNC1865, 1887; ex Pl. leopardus, JNC2126; ex Va. louti, JNC1629, 1662, 1756, 1757, 1859, 2116, 2117.

Unid: Larvae, ex Ep. howlandi, JNC1886

\section{Nematoda}

Cam: Procamallanus variolae ex Va. albimarginata, MNHN JNC1427*; HCIP N-864; ex Ep. fasciatus, JNC1253. Phil: Philometra cyanopodi, ex Ep. cyanopodus, MHNH JNC546*, 1998-2000*; HCIP N-896*

Phil: Philometra fasciati, ex Ep. fasciatus, MNHN JNC1251*, 1257-8*; HCIP N-898*

Phil: Philometra ocularis, ex Ep. coioides, MNHN JNC1535; ex Ep. areolatus, JNC2017; ex Ep. rivulatus, JNC1368; ex Va. louti, JNC1406.

Fish

Ce. urodeta, MNHN 2004-2170; Ep. coeruleopunctatus, 2006-1706; Ep. fasciatus, 2004-2167; Ep. howlandi, 2004-2168-9, 2005-0778, 2005-1360-72, 2006-1333; Ep. maculatus, 2004-2166; Ep. merra, 2004-2171; Va. albimarginata, 2004-2163, 2005-0775, 2005-1014; Va. louti, 2004 2165, 2005-0774, 2005-1013. 


\section{REFERENCES}

Abdou N.E.-S., Palm H.W. 2008: New record of two genera of trypanorhynch cestodes infecting Red Sea fishes in Egypt. J. Egypt. Soc. Parasitol. 38: 281-92.

Anderson R.C. 2000: Nematode Parasites of Vertebrates. Their Development and Transmission. 2nd Ed. CABI Publishing, Oxon and New York, 650 pp.

Arthur J.R., Ahmed A.T.A. 2002: Checklist of the Parasites of Fishes of Bangladesh. FAO, Rome, 77 pp.

Arthur J.R., Lumanlan-Mayo S. 1997: Checklist of the Parasites of Fishes of the Philippines. FAO, Rome, 102 pp.

Arthur J.R., Te B.Q. 2006: Checklist of the Parasites of Fishes of Viet Nam. FAO, Rome, 133 pp.

Beumer J.P., Ashburner L.D., Burbury M.E., Jetté E., Latham D.J. 1983: A Checklist of the Parasites of Fishes from Australia and its Adjacent Antarctic Territories. CAB, Farnham Royal, $99 \mathrm{pp}$.

Beveridge I., Campbell R.A., Jones M.K. 2000: New records of the cestode genus Pseudotobothrium (Trypanorhyncha: Otobothriidae) from Australian fishes. Trans. R. Soc. S. Aust. 124: 151-162.

Beveridge I., Chauvet C., Justine J.-L. 2007: Redescription of Pseudogilquinia pillersi (Southwell, 1929) (Cestoda, Trypanorhyncha) from serranid and lethrinid fishes from New Caledonia and Australia. Acta Parasitol. 52: 213-218.

Beveridge I., Justine J.-L. 2007: Pseudolacistorhynchus nanus n. sp. (Cestoda: Trypanorhyncha) parasitic in the spiral valve of the Zebra Shark, Stegostoma fasciatum (Hermann, 1783). Trans. R. Soc. S. Aust. 132: 175-181.

Bondad-Reantaso M.G., Kanchanakhan S., Chinabut S. 2002: Review of grouper diseases and health management strategies for grouper and other marine finfish diseases. In: Report of the Regional Workshop on Sustainable Seafarming and Grouper Aquaculture, Medan, Indonesia, 17-20 April 2000. Collaborative APEC Grouper Research and Development Network (FWG 01/99). APEC/NACA/BOBP/GOI, Network of Aquaculture Centres in Asia-Pacific, Bangkok, Thailand, pp. 61-92.

Bouchet P. 2006: The magnitude of marine biodiversity. In: C.M. Duarte (Ed.), The Exploration of Marine Biodiversity. Scientific and Technological Challenges. Fundacion BBVA, Bilbao, pp. 31-64.

Boxshall G.A., Lin C.-L., Ho J.-S., Ohtsuka S., Venmathi Maran B.A., Justine J.-L. 2008: A revision of the family Dissonidae (Copepoda: Siphonostomatoida). Syst. Parasitol. 70: 81-106.

Bray R.A., Justine J.-L. 2006a: Prosorhynchus maternus sp. n. (Digenea: Bucephalidae) from the Malabar grouper Epinephelus malabaricus (Perciformes: Serranidae) off New Caledonia. Folia Parasitol. 53: 181-188.

Bray R.A., Justine J.-L. 2006b: Hypocreadium toombo n. sp. (Digenea: Lepocreadiidae) in the yellow-spotted triggerfish Pseudobalistes fuscus (Perciformes: Balistidae) and additional lepocreadiids parasitizing fishes from the waters off New Caledonia. Zootaxa 1326: 37-44.

Bray R.A., Justine J.-L. 2007: Pseudopycnadena tendu sp. nov. (Digenea, Opecoelidae) in the yellow-spotted triggerfish Pseudobalistes fuscus (Perciformes, Balistidae) and additional opecoelids parasitizing fishes from the waters off New Caledonia. Acta Parasitol. 52: 13-17.

Bray R.A., Justine J.-L. 2008: Sympatric species of Deretrema Linton, 1910: D. combesae n. sp. and D. combesorum n. sp. (Digenea: Zoogonidae) from the manybar goatfish Parupeneus multifasciatus (Quoy \& Gaimard, 1824) (Perciformes: Mullidae) from New Caledonia. Parasitol. Int. 57: 18-24.

Bray R.A., Cribb T.H., Justine J.-L. 2009a: New observations on the genus Hypocreadium Ozaki, 1936 (Digenea: Lepocreadiidae) in the Indo-West Pacific region, including the description of one new species. Zootaxa 2110: 22-40.

Bray R.A., Justine J.-L., Cribb T.H. 2009b: Cableia balistidico$l a$ n. sp. (Digenea, Monorchiidae) from Pacific Ocean balistids (Tetraodontiformes) and new reports of Cableia pudica Bray, Cribb and Barker, 1996 in temperate Australian monacanthids. Parasitol. Int. 58: 341-345.

Brooks D.R., Hoberg E.P. 2000: Triage for the biosphere: the need and rationale for taxonomic inventories and phylogenetic studies of parasites. Comp. Parasitol. 67: 1-5.

Campbell R.A., Beveridge I. 1994: Order Trypanorhyncha Diesing, 1863. In: L.F. Khalil, A. Jones and R.A. Bray (Eds.), Keys to the Cestode Parasites of Vertebrates. CAB International, Wallingford, pp. 51-148.

Capart A. 1959: Copépodes Parasites. In: Résultats Scientifiques de l'Expédition Océanographique Belge dans les eaux côtières Africaines de l'Atlantique Sud (1948-1949), pp. 55-126.

Chambers C.B., Cribi T.H., Jones M.K. 2000: Tetraphyllidean metacestodes of teleosts of the Great Barrier Reef, and the use of in vitro cultivation to identify them. Folia Parasitol. 47: 285-292.

Cressey R.F., Cressey H.B. 1980: Parasitic copepods of mackerel- and tuna-like fishes (Scombridae) of the world. Smithson. Contrib. Zool. 311: 1-186.

Cribi T.H. 1998: The diversity of the Digenea of Australian animals. Int. J. Parasitol. 28: 899-911.

Cribb T.H., Bray R.A. 2010: Gut wash, body soak, blender, and heat fixation: approaches to the effective collection, fixation and preservation of trematodes of fishes. Syst. Parasitol. 76: $1-7$.

Cribb T.H., Bray R.A., Wright T., Pichelin S. 2002: The trematodes of groupers (Serranidae: Epinephelinae): knowledge, nature and evolution. Parasitology 124: S23-S42.

Delaney M. 1989: Phylogeny and Biogeography of the Marine Isopod Family Corallanidae (Crustacea, Isopoda, Flabellifera). Contrib. Sci. (Los Angel.) No. 409, 75 pp.

Dove A.D.M., Cribi T.H. 2006: Species accumulation curves and their applications in parasite ecology. Trends Parasitol. 22: 568-574.

Durio W.O., Manter H.W. 1968a: Some digenetic trematodes of marine fishes of New Caledonia. Part I. Bucephalidae, Monorchiidae, and some smaller families. Proc. Helminthol. Soc. Wash. 35: 143-153.

Durio W.O., Manter H.W. 1968b: Some digenetic trematodes of marine fishes of New Caledonia. Part II. Opecoelidae and Lepocreadiidae. J. Parasitol. 54: 747-756.

Euzet L. 1994: Order Tetraphyllidea. In: L.F. Khalil, A. Jones and R.A. Bray (Eds.), Keys to the Cestode Parasites of Vertebrates. CAB International, Wallingford, pp. 149-194.

Euzet L., Combes C. 1980: Les problèmes de l'espèce chez les animaux parasites. In: C. Boquet, J. Génermont and M. Lamotte (Eds.), Les Problèmes de l'Espèce dans le Règne Animal. Mémoires No. 40 de la Société Zoologique de France, Vol. 3, pp. 239-285.

Fricke R., Kulbicki M. 2007: Checklist of the shore fishes of New Caledonia. In: C.E. Payri and B. Richer de Forges (Eds.), Compendium of Marine Species from New Caledonia. Documents Scientifiques et Techniques Vol. II7, Deuxième Edition. Institut 
de Recherche pour le Développement, Nouméa, New Caledonia, pp. 357-401.

Froese R., Pauly D. 2009: FishBase. World Wide Web electronic publication. www.fishbase.org. Version 10/2009.

Goggio E. 1905: Intorno al gen. Clavella (Hatschekia Poche). Arch. Zool. Napoli 2: 215-225.

Gunter N.L., Adlard R.D. 2009: Seven new species of Ceratomyxa Thélohan, 1892 (Myxozoa) from the gall-bladders of serranid fishes from the Great Barrier Reef, Australia. Syst. Parasitol. 73: 1-11.

Healy C.J., Caira J.N., Jensen K., Webster B.L., Littlewood D.T.J. 2009: Proposal for a new tapeworm order, Rhinebothriidea. Int. J. Parasitol. 39: 497-511.

Heemstra P.C., Randall J.E. 1993: FAO Species Catalogue. Vol. 16. Groupers of the World (Family Serranidae, Subfamily Epinephelinae). An Annotated and Illustrated Catalogue of the Grouper, Rockcod, Hind, Coral Grouper and Lyretail Species Known to Date. FAO, Rome, 382 pp.

Hinsinger D.D., Justine J.-L. 2006a: The 'Pseudorhabdosynochus cupatus group' (Monogenea: Diplectanidae) on Epinephelus fasciatus, E. howlandi, E. rivulatus and E. merra (Perciformes: Serranidae) off New Caledonia, with descriptions of Pseudorhabdosynochus cyathus n. sp. and P. calathus n. sp. Syst. Parasitol. 64: 69-90.

Hinsinger D.D., Justine J.-L. 2006b: Pseudorhabdosynochus venus n. sp. (Monogenea: Diplectanidae) from Epinephelus howlandi (Perciformes: Serranidae) off New Caledonia. Syst. Parasitol. 63: 155-160.

Ho J., Dojiri M. 1978: A new species of Hatschekia (Copepoda: Dichelesthiidae) parasitic on leopard coral trout in the Great Barrier Reef, Australia. J. Parasitol. 64: 727-730.

Ho J.S., DojiRi M. 1977: Parasitic copepods on the fishes of the Great Barrier Reef, Australia. Part II. Caligoida: Dissonus, Lepeophtheirus, and Dentigryps. Publ. Seto Mar. Biol. Lab. 24: 77-97.

Hoberg E.P., Pilitt P.A., Galbreath K.E. 2009: Why museums matter: a tale of pinworms (Oxyuroidea: Heteroxynematidae) among pikas (Ochotona princeps and $O$. collaris) in the American West. J. Parasitol. 95: 490-501.

Jones D.A. 1982: New isopods of the genus Lanocira from the Indian Ocean region. Crustaceana 42: 65-75.

Jones G.P., McCormick M.I., SRinivasan M., Eagle J.V. 2004: Coral decline threatens fish biodiversity in marine reserves. Proc. Natl. Acad. Sci. U. S. A. 101: 8251-8253.

Journo C., Justine J.-L. 2006: Laticola dae n. sp. (Monogenea: Diplectanidae) from Epinephelus maculatus (Perciformes: Serranidae) off New Caledonia. Syst. Parasitol. 64: 173-180.

Justine J.-L. 2005a: Species of Pseudorhabdosynochus Yamaguti, 1958 (Monogenea: Diplectanidae) from Epinephelus fasciatus and E. merra (Perciformes: Serranidae) off New Caledonia and other parts of the Indo-Pacific Ocean, with a comparison of measurements of specimens prepared using different methods, and a description of P. caledonicus n. sp. Syst. Parasitol. 62: $1-37$.

Justine J.-L. 2005b: Pseudorhabdosynochus hirundineus n. sp. (Monogenea: Diplectanidae) from Variola louti (Perciformes: Serranidae) off New Caledonia. Syst. Parasitol. 62: 39-45.

Justine J.-L. 2007a: Fish parasites: Platyhelminthes (Monogenea, Digenea, Cestoda) and Nematodes, reported from off New Caledonia. In: C.E. Payri and B. Richer de Forges (Eds.), Compendium of Marine Species from New Caledonia. Documents Scientifiques et Techniques Vol. II7, Deuxième Edition. Institut de Recherche pour le Développement, Nouméa, New Caledonia, pp. 183-198.
JUSTINE J.-L. 2007b: Parasite biodiversity in a coral reef fish: twelve species of monogeneans on the gills of the grouper Epinephelus maculatus (Perciformes: Serranidae) off New Caledonia, with a description of eight new species of Pseudorhabdosynochus (Monogenea: Diplectanidae). Syst. Parasitol. 66: 81-129.

Justine J.-L. 2007c: Pseudorhabdosynochus argus n. sp. (Monogenea: Diplectanidae) from Cephalopholis argus, P. minutus $\mathrm{n}$. sp. and Diplectanum nanus n. sp. from C. sonnerati and other monogeneans from Cephalopholis spp. (Perciformes: Serranidae) off Australia and New Caledonia. Syst. Parasitol. 68: 195-215.

Justine J.-L. 2007d: Species of Calydiscoides Young, 1969 (Monogenea: Diplectanidae) from lethrinid fishes, with the redescription of all of the type-specimens and the description of C. euzeti n. sp. from Lethrinus rubrioperculatus and L. xanthochilus off New Caledonia. Syst. Parasitol. 67: 187-209.

Justine J.-L. 2008a: Diplectanum parvus sp. nov. (Monogenea, Diplectanidae) from Cephalopholis urodeta (Perciformes, Serranidae) off New Caledonia. Acta Parasitol. 53: 127-132.

Justine J.-L. 2008b: Pseudorhabdosynochus inversus sp. nov. (Monogenea, Diplectanidae) from the halfmoon grouper Epinephelus rivulatus (Perciformes, Serranidae) off New Caledonia. Acta Parasitol. 53: 339-343.

Justine J.-L. 2008c: Two new species of Pseudorhabdosynochus Yamaguti, 1958 (Monogenea: Diplectanidae) from the deep-sea grouper Epinephelus morrhua (Val.) (Perciformes: Serranidae) off New Caledonia. Syst. Parasitol. 71: 145-158.

Justine J.-L. 2009: A redescription of Pseudorhabdosynochus epinepheli (Yamaguti, 1938), the type-species of Pseudorhabdosynochus Yamaguti, 1958 (Monogenea, Diplectanidae), and the description of P. satyui $\mathrm{n}$. sp. from Epinephelus akaara off Japan. Syst. Parasitol. 72: 27-55.

Justine J.-L. 2010: Parasites of coral reef fish: how much do we know? With a bibliography of fish parasites in New Caledonia. Belg. J. Zool. 140 (Suppl.): 155-190.

Justine J.-L., BRiand M.J. 2010: Three new species, Lamellodiscus tubulicornis n. sp., L. magnicornis $\mathrm{n}$. sp. and L. parvicornis n. sp. (Monogenea: Diplectanidae) from Gymnocranius spp. (Lethrinidae: Monotaxinae) off New Caledonia, with proposal of the new morphological group 'tubulicornis' within Lamellodiscus Johnston \& Tiegs, 1922. Syst. Parasitol. 75: 159-179.

Justine J.-L., Dupoux C., Cribb T.H. 2009a: Resolution of the discrepant host-specificity of Pseudorhabdosynochus species (Monogenea, Diplectanidae) from serranid fishes in the tropical Indo-Pacific. Acta Parasitol. 54: 119-130.

Justine J.-L., Euzet L. 2006: Diplectanids (Monogenea) parasitic on the gills of the coralgroupers Plectropomus laevis and P. leopardus (Perciformes, Serranidae) off New Caledonia, with the description of five new species and the erection of Echinoplectanum n. g. Syst. Parasitol. 64: 147-172.

Justine J.-L., Leblanc P., Keller F., Lester R.J.G. 2009b: Turbellarian black spot disease in bluespine unicornfish, Naso unicornis in New Caledonia, caused by the parasitic turbellarian Piscinquilinus sp. Dis. Aquat. Org. 85: 245-249.

Justine J.-L., Sigura A. 2007: Monogeneans of the malabar grouper Epinephelus malabaricus (Perciformes, Serranidae) off New Caledonia, with a description of six new species of Pseudorhabdosynochus (Monogenea: Diplectanidae). Zootaxa 1543: 1-44.

Kaвata Z. 1965: Copepoda parasitic on Australian fishes, IV. Genus Caligus (Caligidae). Ann. Mag. Nat. Hist. 13: 109-126.

Kabata Z. 1966: Copepoda parasitic on Australian fishes, VI. Some caligoid species. Ann. Mag. Nat. Hist. 13: 563-570. 
Khalil L.F., Jones A., Bray R.A. 1994: Keys to the Cestode Parasites of Vertebrates. CAB International, Wallingford, $751 \mathrm{pp}$.

Kritsky D.C., Yang T., Sun Y. 2009: Dactylogyrids (Monogenoidea, Polyonchoinea) parasitizing the gills of snappers (Perciformes, Lutjanidae): Proposal of Haliotrematoides n. gen. and descriptions of new and previously described species from marine fishes of the Red Sea, the eastern and Indo-west Pacific Ocean, Gulf of Mexico and Caribbean Sea. Zootaxa 1970: 1-51.

Kuchta R., Scholz T., Brabec J., Bray R.A. 2008: Suppression of the tapeworm order Pseudophyllidea (Platyhelminthes: Eucestoda) and the proposal of two new orders, Bothriocephalidea and Diphyllobothriidea. Int. J. Parasitol. 38: 49-55.

Kuchta R., Scholz T., Justine J.-L. 2009a: Two new species of Bothriocephalus (Cestoda: Bothriocephalidea) from marine fish from Australia and New Caledonia. Syst. Parasitol. 73: 229-238.

Kuchta R., Scholz T., Vlčková R., Rína M., Walter T., YuNiar A.T., Palm H.W. 2009b: Revision of tapeworms (Cestoda: Bothriocephalidea) from lizardfish (Saurida: Synodontidae) from the Indo-Pacific region. Zootaxa 1977: 55-67.

Kulbicki M., Guillemot N., Amand M. 2005: A general approach to length-weight relationships for New Caledonian lagoon fishes. Cybium 29: 235-253.

Lafferty K.D., Shaw J.C., Kuris A.M. 2008: Reef fishes have higher parasite richness at unfished Palmyra Atoll compared to fished Kirimati Island. EcoHealth 5: 338-345.

Lawton J.H., Bignell D.E., Bolton B., Bloemers G.F., Eggleton P., Hammond P.M., Hodda M., Holt R.D., Larsen T.B., Mawdsley N.A., Stork N.E., Srivastava D.S., Watt A.D. 1998: Biodiversity inventories, indicator taxa and effects of habitat modification in tropical forest. Nature 391: 72-76.

Lester R.J.G., Sewell K.B. 1989: Checklist of parasites from Heron Island, Great Barrier Reef. Aust. J. Zool. 37: 101-128.

Lewis A.G. 1967: Copepod crustaceans parasitic on teleost fishes of the Hawaiian islands. Proc. U. S. Natl. Mus. 121: 1-204.

Liм L.H.S. 1998: Diversity of monogeneans in Southeast Asia. Int. J. Parasitol. 28: 1495-1515.

Lim L.H.S., Justine J.-L. 2007: Haliotrema banana sp. n. (Monogenea: Ancyrocephalidae) from Bodianus perditio (Perciformes: Labridae) off New Caledonia. Folia Parasitol. 54: 203207.

Lo C.M., Morgan J.A.T., Galzin R., Cribb T.H. 2001: Identical digeneans in coral reef fishes from French Polynesia and the Great Barrier Reef (Australia) demonstrated by morphology and molecules. Int. J. Parasitol. 31: 1573-1578.

Luque J.L., Poulin R. 2007: Metazoan parasite species richness in Neotropical fishes: hotspots and the geography of biodiversity. Parasitology 134: 865-878.

Manter H.W. 1969: Some digenetic trematodes of marine fishes of New Caledonia. Part IV. Hemiuridae and summary. Proc. Helminthol. Soc. Wash. 36: 194-204.

Marie A.D., Justine J.-L. 2006: Thaumatocotyle pseudodasybatis Hargis, 1955 (Monogenea: Monocotylidae) from Aetobatus cf. narinari, with a comparison of specimens from Australia, French Polynesia and New Caledonia. Syst. Parasitol. 64: 4755.

Monod T. 1933: Tanaidacea et Isopoda. Mission Robert-Ph. Dollfus en Égypte. Mém. Inst. Égypte 21: 161-264.

Monod T. 1975: Sur un Argathona (Crustacea, Isopoda) du Kenya. Bull. Mus. Natl. Hist. Nat., Paris, 3ème sér., Zool. 226: 9991004.

Moravec F. 1994: Parasitic Nematodes of Freshwater Fishes of Europe. Academia, Praha, 476 pp.
MoraVec F. 2006: Dracunculoid and Anguillicoloid Nematodes Parasitic in Vertebrates. Academia, Praha, 634 pp.

Moravec F., Justine J.-L. 2005: Two species of Philometra (Nematoda, Philometridae) from serranid fishes off New Caledonia. Acta Parasitol. 50: 323-331.

Moravec F., Justine J.-L. 2008: Some philometrid nematodes (Philometridae), including four new species of Philometra, from marine fishes off New Caledonia. Acta Parasitol. 53: 369-381.

Moravec F., Justine J.-L. 2009: New data on dracunculoid nematodes from fishes off New Caledonia, including four new species of Philometra (Philometridae) and Ichthyofilaria (Guyanemidae). Folia Parasitol. 56: 129-142.

Moravec F., Justine J.-L. 2010: Two new genera and species of cystidicolids (Nematoda, Cystidicolidae) from marine fishes off New Caledonia. Parasitol. Int. 59: 198-205.

Moravec F., Justine J.-L., Rigby M.C. 2006: Some camallanid nematodes from marine perciform fishes off New Caledonia. Folia Parasitol. 53: 223-239.

Muñoz G., Grutter A.S., CRibB T.H. 2007: Structure of the parasite communities of a coral reef fish assemblage (Labridae): testing ecological and phylogenetic host factors. J. Parasitol. 93: $17-30$.

Nunes-Ruivo L.P. 1954: Parasites des poissons de mer ouestafricains récoltés par M.J. Cadenat. III. Copépodes (2e note). Genres Prohatschekia n. gen. et Hatschekia Poche. Bull. Inst. Fr. Afr. Noire 16: 479-505.

Nunes-Ruivo L.P., Fourmanoir P. 1956: Copépodes parasites de poissons de Madagascar. Mém. Inst. Sci. Madag. 10: 69-80.

Ottolenghi F., Silvestri C., Giordano P., Lovatelli A., New M.B. 2004: Capture-Based Aquaculture. The Fattening of Eels, Groupers, Tunas and Yellowtails. FAO, Rome, 308 pp.

Palm H.W. 2004: The Trypanorhyncha Diesing, 1863. PKSPL-IPB Press, Bogor, 710 pp.

Perkins E.M., Donnellan S.C., Bertozzi T., Chisholm L.A., WhitTington I.D. 2009: Looks can deceive: Molecular phylogeny of a family of flatworm ectoparasites (Monogenea: Capsalidae) does not reflect current morphological classification [with list of species in Appendix 1 in Additional Material]. Mol. Phylogenet. Evol. 52: 705-714.

Pillai N.K., Sebastian M.J. 1967: Redescription of Sagum epinepheli (Yamaguti \& Yamasu) with comments on the validity of Pseudolernanthropus (Copepoda, Anthosomatidae). Crustaceana 13: 73-80.

Plaisance L., Littlewood D.T.J., Olson P.D., Morand S. 2005: Molecular phylogeny of gill monogeneans (Platyhelminthes, Monogenea, Dactylogyridae) and colonization of Indo-west Pacific butterflyfish hosts (Perciformes, Chaetodontidae). Zool. Scr. 34: 425-436.

Plaisance L., Rousset V., Morand S., Littlewood D.T.J. 2008: Colonization of Pacific islands by parasites of low dispersal ability: phylogeography of two monogenean species parasitizing butterflyfishes in the South Pacific Ocean. J. Biogeogr. 35: 76-87.

Poulin R. 2004: Parasite species richness in New Zealand fishes: a grossly underestimated component of biodiversity? Divers. Distrib. 10: 31-37.

Poulin R., Justine J.-L. 2008: Linking species abundance distributions and body size in monogenean communities. Parasitol. Res. 103: 187-193.

Pozdnyakov S.E., Gibson D.I. 2008: Family Didymozoidae Monticelli, 1888. In: R.A. Bray, D.I. Gibson and A. Jones (Eds.), Keys to the Trematoda, Vol. 3. CAB International and The Natural History Museum, London, pp. 631-734. 
Quiazon K.M.A., Yoshinaga T., Ogawa K. 2008a: Taxonomical study into two new species of Philometra (Nematoda: Philometridae) previously identified as Philometra lateolabracis (Yamaguti, 1935). Folia Parasitol. 55: 29-41.

Quiazon K.M.A., Yoshinaga T., Ogawa K. 2008b: Philometra sawara sp. $\mathrm{n}$. and a redescription of Philometra sciaenae Yamaguti, 1941 and Philometra nemipteri Luo, 2001 (Nematoda: Philometridae): a morphological and molecular approach. Folia Parasitol. 55: 277-290.

Randall J.E., Justine J.-L. 2008: Cephalopholis aurantia $\times$ C. spiloparaea, a hybrid serranid fish from New Caledonia. Raffles Bull. Zool. 56: 149-151.

Rascalou G., Justine J.-L. 2007: Three species of Calydiscoides (Monogenea: Diplectanidae) from five Lethrinus spp. (Lethrinidae: Perciformes) off New Caledonia, with a description of $\mathrm{Ca}$ lydiscoides terpsichore sp. n. Folia Parasitol. 54: 191-202.

Reaka-Kudla M.L. 1997: The global biodiversity of coral reefs: a comparison with rain forests. In: M.L. Reaka-Kudla, D.E. Wilson and E.O. Wilson (Eds.), Biodiversity II: Understanding and Protecting our Biological Resources. Joseph Henry Press, Washington, pp. 83-108.

Řehulková E., Justine J.-L., Gelnar M. 2010: Five new monogenean species from the gills of Mulloidichthys vanicolensis (Perciformes: Mullidae) off New Caledonia, with the proposal of Volsellituba n. gen. and Pennulituba n. gen. (Monogenea: Dactylogyridae). Syst. Parasitol. 75: 125-145.

Reversat J., Maillard C., Silan P. 1991: Polymorphismes phénotypique et enzymatique: intérêt et limites dans la description d'espèces d'Helicometra (Trematoda: Opecoelidae), mésoparasites de téléostéens marins. Syst. Parasitol. 19: 147-158.

Reversat J., Renaud F., Maillard C. 1989: Biology of parasite populations: the differential specificity of the genus Helicometra Odhner, 1902 (Trematoda: Opecoelidae) in the Mediterranean Sea demonstrated by enzyme electrophoresis. Int. J. Parasitol. 19: 885-890.

Reversat J., Silan P. 1993: Comparative population biology of fish digenes: the case of three Helicometra (Trematoda: Opecoelidae) mesoparasites of marine teleosts in a Mediterranean lagoon. Ann. Parasitol. Hum. Comp. 68: 128-135.

Rigby M.C., Holmes J.C., Cribi T.H., Morand S. 1997: Patterns of species diversity in the gastrointestinal helminths of a coral reef fish, Epinephelus merra (Serranidae), from French Polynesia and the South Pacific Ocean. Can. J. Zool. 75: 1818-1827.

Rigby M.C., Lo C.M., Cribb T.H., Euzet L., Faliex E., Galzin R., Holmes J.C., Morand S. 1999: Checklist of the parasites of coral reef fishes from French Polynesia, with considerations on their potential role in these fish communities. Cybium 23: 273-284.

Roberts C.M., McClean C.J., Veron J.E.N., Hawkins J.P., Allen G.R., McAllister D.E., Mittermeier C.G., Schueler F.W., Spalding M., Wells F., Vynne C., Werner T.B. 2002: Marine biodiversity hotspots and conservation priorities for tropical reefs. Science 295: 1280-1284.
RoHDE K. 1976: Marine parasitology in Australia. Search (Sydney) 7: 477-482.

Sekerak A.D., Arai H.P. 1974: A revision of Helicometra Odhner, 1902 and related genera (Trematoda: Opecoelidae), including a description of Neohelicometra sebastis $\mathrm{n}$. sp. Can. J. Zool. 52: 707-738.

Shirno S.M. 1957: Copepods parasitic on Japanese fishes. 15. Eudactylinidae and Dichelesthiidae. Rep. Fac. Fish. Univ. Mie 2: 403-410.

Sigura A., Chauvet C., Justine J.-L. 2007: Pseudorhabdosynochus bacchus sp. nov. (Monogenea, Diplectanidae) from Epinephelus coeruleopunctatus (Perciformes, Serranidae) off New Caledonia. Acta Parasitol. 52: 196-200.

Sigura A., Justine J.-L. 2008: Monogeneans of the speckled blue grouper, Epinephelus cyanopodus (Perciformes, Serranidae), from off New Caledonia, with a description of four new species of Pseudorhabdosynochus and one new species of Laticola (Monogenea: Diplectanidae), and evidence of monogenean faunal changes according to the size of fish. Zootaxa 1695: 1-44.

Smit N.J., Basson L., Van As J.G. 2003: Life cycle of the temporary fish parasite, Gnathia africana (Crustacea: Isopoda: Gnathiidae). Folia Parasitol. 50: 135-142.

Trilles J.-P., Justine J.-L. 2010: Elthusa epinepheli sp. nov. (Crustacea, Isopoda, Cymothoidae) a branchial parasite of the grouper Epinephelus howlandi (Serranidae, Epinephelinae) from off New Caledonia. Acta Parasitol. 55: 177-187.

WhitTington I.D. 1998: Diversity "down under": monogeneans in the Antipodes (Australia) with a prediction of monogenean biodiversity worldwide. Int. J. Parasitol. 28: 1481-1493.

Whittington I.D. 2004: The Capsalidae (Monogenea: Monopisthocotylea): a review of diversity, classification and phylogeny with a note about species complexes. Folia Parasitol. 51: 109-122.

Whittington I.D., Chisholm L.A. 2003: Biodiversity of marine parasites in Australia: More than just a list of largely invisible creatures. Rec. S. Aust. Mus. Monogr. Ser. 7: 51-60.

Williams E.H., Bunkley-Williams L., Dyer W.G. 1996: Metazoan parasites of some Okinawan coral reef fishes with a general comparison to the parasites of Caribbean coral reef fishes. Galaxea 13: 1-13.

Williams H., Jones A. 1994: Parasitic Worms of Fish. Taylor and Francis, London, $593 \mathrm{pp}$.

Windsor D.A. 1998: Most of species on Earth are parasites. Int. J. Parasitol. 28: 1939-1941.

Yamaguti S. 1968: Monogenetic Trematodes of Hawaiian fishes. University of Hawaii Press, Honolulu, 287 pp.

Yamaguti S. 1970: Digenetic Trematodes of Hawaiian Fishes. Keigaku, Tokyo, 436 pp.

Yamaguti S., Yamasu T. 1960: New parasitic copepods from Japanese fishes. Publ. Seto Mar. Biol. Lab. 8: 141-152.

YANG W. 2007: A list of fish cestodes reported from China. Syst. Parasitol. 68: 71-78.

Zhang J., YAng T., Liu L., Ding X. 2003: A list of monogeneans from Chinese marine fishes. Syst. Parasitol. 54: 111-130. 